\title{
1 A novel approach to concentrate human and animal viruses 2 from wastewater using receptors-conjugated magnetic beads

4 Chamteut $\mathrm{Oh}^{1}$, Kyukyoung Kim² ${ }^{2}$, Elbashir Araud ${ }^{3}$, Leyi Wang ${ }^{4}$, Joanna L. Shisler ${ }^{5}$, Thanh H. Nguyen $^{1,6}$ Corresponding authors: Chamteut Oh (ㅁ14@illinois.edu)

1) Department of Civil and Environmental Engineering, University of Illinois at UrbanaChampaign, USA

2) Department of Chemical and Biomolecular Engineering, University of Illinois at UrbanaChampaign, USA

3) Holonyak Micro \& Nanotechnology Lab, University of Illinois at Urbana-Champaign

4) Veterinary Diagnostic Laboratory and Department of Veterinary Clinical Medicine, University of Illinois at Urbana-Champaign, United States

5) Department of Microbiology, University of Illinois at Urbana-Champaign, USA

6) Institute of Genomic Biology, University of Illinois at Urbana-Champaign, USA 
medRxiv preprint doi: https://doi.org/10.1101/2021.12.07.21267392; this version posted December 8, 2021. The copyright holder for this preprint (which was not certified by peer review) is the author/funder, who has granted medRxiv a license to display the preprint in perpetuity.

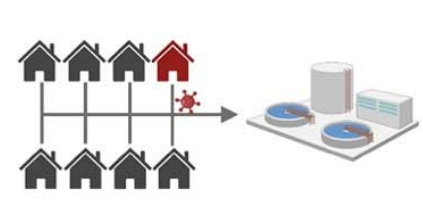

Wastewater

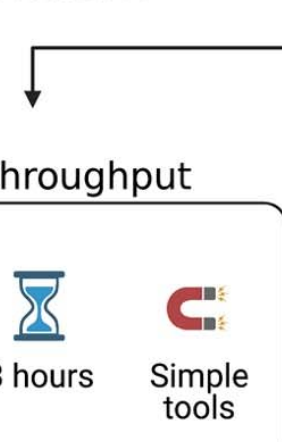

High throughput

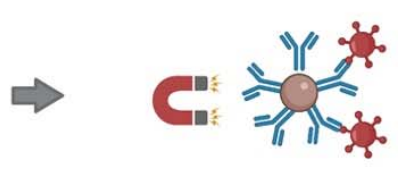

PGM-MBs method
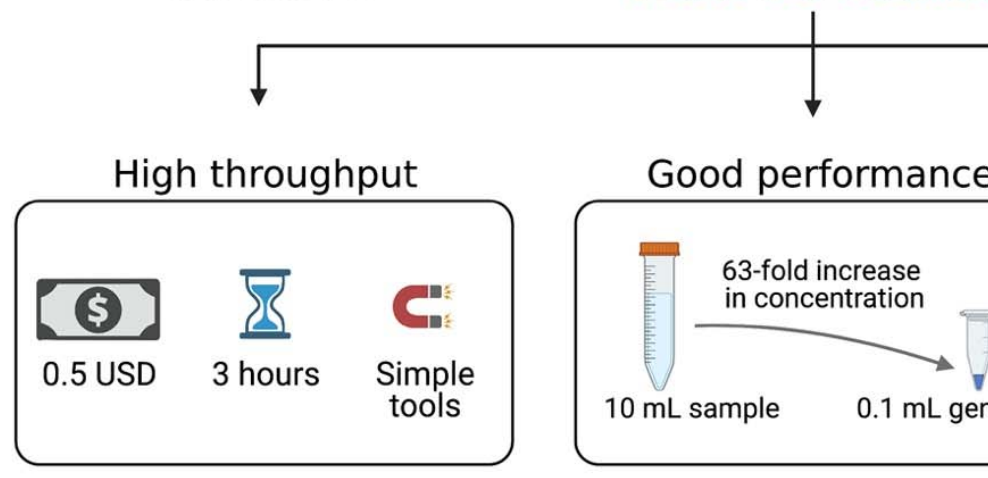

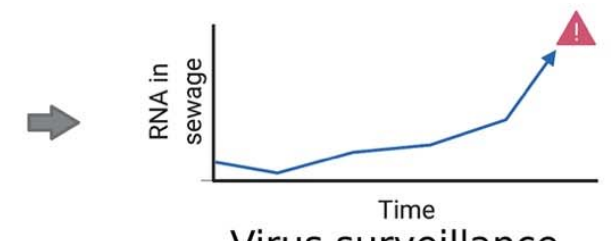

Virus surveillance

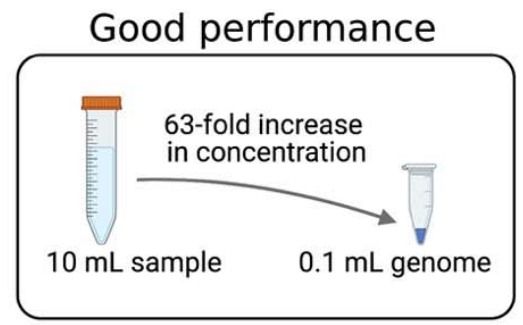

Robust to environmental samples

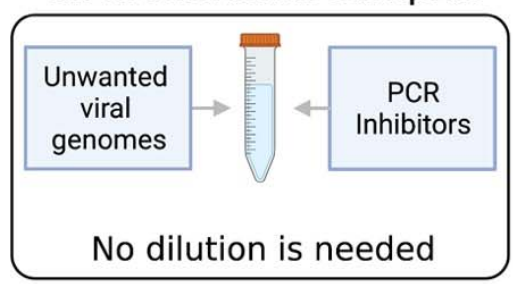

25 


\section{Abstract}

28 Viruses are present at low concentrations in wastewater, and therefore an effective concentration

29 of virus particles is necessary for accurate wastewater-based epidemiology (WBE). We designed

30 a novel approach to concentrate human and animal viruses from wastewater using porcine gastric

31 mucin-conjugated magnetic beads (PGM-MBs). We systematically evaluated the performances

32 of the PGM-MBs method (sensitivity, specificity, and robustness to environmental inhibitors)

33 with six viral species including Tulane virus (a surrogate for human norovirus), rotavirus,

34 adenovirus, porcine coronavirus (transmissible gastroenteritis virus or TGEV), and two human

35 coronaviruses (NL63 and SARS-CoV-2) in influent wastewater and raw sewage samples. We

36 determined the multiplication factor (the ratio of genome concentration of the concentrated over

37 that of the initial solution) for the PGM-MBs method, which ranged from 1.3 to 64.0 depending

38 on the viral species. Because the recovery efficiency became significantly higher when

39 calculated based on virus titers than genome concentration, the PGM-MBs method could be an

40 appropriate tool for assessing the risk due to wastewater contaminated with infectious enteric

41 viruses. PCR inhibitors were not concentrated by PGM-MBs, suggesting this tool will be

42 successful for use with environmental samples. The PGM-MBs method is cost-effective $(0.43$

$43 \mathrm{USD} /$ sample) and fast turnaround (3 hours from virus concentration to genome quantification),

44 and thus this method can be implemented for high throughput facilities. Based on good

45 performance, intrinsic characteristics of targeting the infectious virus, robustness to wastewater,

46 and adaptability to high throughput systems, we are confident that the PGM-MBs method can be

47 applied for successful WBE and ultimately provides valuable public health information.

48 Keywords (maximum 6): Porcine gastric mucin conjugated magnetic beads (PGM-MBs); virus

49 concentration method; wastewater-based epidemiology; SARS-CoV-2; enteric viruses 


\section{Introduction}

51 Enteric viruses are the leading cause of gastroenteritis worldwide. Many enteric viruses, such as

52 rotavirus, norovirus, and adenoviruses, are shed in fecal material (Kang, 2017; Kapikian, 1996).

53 Other airborne viruses, like SARS-CoV-2, are also shed in the human stool (Hu et al., 2020).

54 Thus, wastewater-based epidemiology (WBE) can be a powerful tool to detect viral transmission

55 in communities even before the appearance of clinical cases (Ahmed et al., 2021; Harris-Lovett

56 et al., 2021; Hart and Halden, 2020; Nemudryi et al., 2020; Panchal et al., 2021; Sherchan et al.,

57 2021). However, virus monitoring faces a challenge that the viral concentration in wastewater

58 may be below the detection limit of analysis instruments such as qPCR system, especially when

59 transmission has just started in communities. Although viruses such as noroviruses, adenoviruses,

60 and enteroviruses are excreted at high concentrations (up to $10^{11}$ viruses/g-feces), the viruses are

61 diluted by different sources of water (Haramoto et al., 2018). For example, Albinana-Gemenez et

62 al. (2006) detected $10^{6}-10^{7}$ gene copies (gc)/L of adenoviruses and polyomaviruses in sewage,

63 but the virus concentrations decreased to $10^{1}$ to $10^{2} \mathrm{gc} / \mathrm{L}$ for river water. Since the lower limit of

64 qPCR detection is about $10^{0} \mathrm{gc} / \mu \mathrm{L}$ (or $10^{6} \mathrm{gc} / \mathrm{L}$ ), viruses from wastewater samples must be

65 concentrated into smaller volumes. There are several strategies available to concentrate viruses

66 from wastewater include ultracentrifugation, ultrafiltration, adsorption/extraction, skimmed-milk

67 flocculation, polyethylene glycol (PEG) precipitation, and sludge extraction methods (Ahmed et

68 al., 2020; Jafferali et al., 2021; Wolfe et al., 2021). However, those conventional virus

69 concentration methods are expensive, time-consuming, and resource-demanding processes

70 (Gibas et al., 2021; LaTurner et al., 2021; Polo et al., 2020), so this process often becomes a

71 bottleneck in monitoring viruses in wastewater. Therefore, there is an urgent need for a new

72 virus concentration method that is simple and fast. 
In the recent past, we and others have coated magnetic beads (MB) with porcine gastric

74 mucin (PGM) to study virus binding properties (Afolayan et al., 2016; Araud et al., 2018;

75 Fuzawa et al., 2019; Oh et al., 2020; Walker et al., 2019). The PGM is a biological substrate that

76 includes molecules (e.g., glycans) that act as virus receptors. Thus, we hypothesize that these

77 PGM-MBs can selectively concentrate viruses from wastewater. An additional benefit of PGM-

$78 \mathrm{MBs}$ is that they can capture infectious virus particles instead of viral genomes, giving a more

79 accurate quantification of risk for WBE.

80 The objective of this research was to design and optimize this receptor-based virus

81 concentration method using porcine gastric mucin conjugated-magnetic beads (PGM-MBs) and

82 evaluate the efficacy of PGM-MBs compared to its conventional counterparts. Fig. S1 shows

83 five steps of the PGM-MBs method from wastewater sample pretreatment, virus attachment,

84 virus concentration, genome extraction, to genome quantification step. We first optimized the

85 method using influent wastewater spiked with five virus strains (Tulane virus (TV), rotavirus

86 (RV), adenovirus (AdV), human coronavirus (NL63), and porcine coronavirus (transmissible

87 gastroenteritis virus; TGEV). We selected these viruses based on their significance for public

88 health and economy (Binder et al., 2017; Fielding, 2011; Katayama et al., 2002; La Rosa et al.,

89 2020a; Lodder and De Roda Husman, 2005; Waruhiu et al., 2017). We systematically evaluated

90 the performances of the PGM-MBs method (sensitivity, specificity, and robustness to

91 environmental inhibitors) with 20 sewage samples spiked with these enteric viruses. In addition,

92 we used PGM-MBs in local sewage samples to concentrate SARS-CoV-2 and compared its

93 performances to electronegative filtration methods, one of the most widely used virus

94 concentration methods. The findings suggest that PGM-MBs can be simple, affordable, but still

95 accurate tools for WBE. 


\section{Materials and Methods}

\subsection{PGM-MBs virus concentration method}

99 The porcine gastric mucin conjugated magnetic beads (PGM-MBs) were produced as described

100 in our previous studies (Araud et al., 2018; Fuzawa et al., 2019; Oh et al., 2020), and the

101 detailed procedure is elaborated in Text S1. The PGM-MBs is suspension that includes 1-4 $\mu \mathrm{m}$

102 diameter beads at a concentration of $2 \times 10^{6}$ beads $/ \mu \mathrm{L}$. The pretreatment of wastewater samples,

103 necessary to remove solid particles that can otherwise interference with subsequent analysis, was

104 achieved by either gravitational settling for 2 hours or filtration through $0.22 \mu \mathrm{m}$ membrane

105 filters (S2GPT02RE, Millipore Sigma, USA). The virus attachment to the PGM-MBs was

106 optimized by changing the $\mathrm{MgCl}_{2}$ concentration between 0 to $100 \mathrm{mM}$. Specifically, the PGM-

$107 \mathrm{MBs}$ and $\mathrm{MgCl}_{2}$ were added to a wastewater sample at a 1:1000 volume ratio and $50 \mathrm{mM}$,

108 respectively. For example, we put $10 \mu \mathrm{L}$ of the PGM-MBs into $10 \mathrm{~mL}$ of the samples for the

109 optimization experiments and $50 \mu \mathrm{L}$ PGM-MBs to $50 \mathrm{~mL}$ sewage for SARS-CoV-2 surveillance.

110 The mixture was shaken for 30 minutes on an orbit shaker at $450 \mathrm{rpm}$ (Fisher Scientific, USA) at

111 room temperature. Then, the virus-containing PGM-MBs were concentrated by a magnet

112 (DH125J-FN, Amazing magnets, USA) placed at the outside surface of the bottom of the tube

113 for about 30 minutes and the clear supernatant was removed. The remaining PGM-MBs and

114 supernatant were collected and transferred to a $1.5 \mathrm{~mL}$ low adhesion microcentrifuge tube (1415-

115 2600, USA scientific, USA). The PGM-MBs were washed three times by sequentially

116 resuspending beads in $1 \mathrm{~mL}$ PBS, collecting beads by using a magnetic separation rack (S1509S,

117 New Biolabs Lab, USA), and removing supernatants. Finally, the viral genomes were extracted

118 by heat denaturation method and quantified by either qPCR or RT-qPCR depending on viral 
119 species, which is elaborated in Section 2.1. Also, Section 3.1 presents the results of the PGM-

120 MBs optimization experiments.

\subsection{Viral nucleic acid extraction and quantification}

123 Commercial nucleic acid extraction kits are expensive, time-consuming and could be in short

124 supply (Satyanarayana, 2020). Therefore, we established a heat denaturation method compatible

125 with the PGM-MBs method to reduce resources (cost, time, and labor). The heat denaturation

126 method started with resuspending a pellet of virus-containing PGM-MBs with $100 \mu \mathrm{L}$ proteinase

127 K (P8107S, New England Biolabs, USA) that was diluted 100-fold by molecular biology grade

128 water (Millipore Sigma) for denaturation of the viral capsid. The mixture was then transferred to

129 a $200 \mu \mathrm{L}-$-size PCR tube (14-222-262, Fisher Scientific, USA) and incubated at 95 $\square$ for 10

130 minutes using a thermal cycler (MyCycler ${ }^{\mathrm{TM}}$, Bio-Rad), followed by quick cooling on ice. While

131 being heated, the viral genomes were released from the capsid, and the proteinase $\mathrm{K}$ was

132 inactivated. The PGM-MBs were pelletized by a magnet (S1509S, New Biolabs Lab, USA) for

133 one minute, and the genomes were taken from the supernatant near the solution surface for

134 further analysis. The concentrations of viral genomes were quantified by SYBR-based RT-qPCR

135 for TV, RV, NL63, and TGEV; Taqman-based RT-qPCR for SARS-CoV-2; , or SYBR-based

136 qPCR for AdV. We used iTaq universal SYBR green reaction mix (Bio-Rad Laboratories, USA)

137 for TV, RV, NL63, and TGEV analysis, PowerUp SYBR ${ }^{\mathrm{TM}}$ Green Master Mix (Applied

138 Biosystems, CA, USA) for AdV quantification, and Taqman Fast Virus 1-step Master Mix

139 (4444432, Applied Biosystems, USA) for SARS-CoV-2. Viral genomes were quantified using a

140 qPCR system (QuantStudio 3, Thermo Fisher Scientific, USA). Table S1 summarized these RT-

141 qPCR methods following the MIQE guidelines (Bustin et al., 2009). Text S2 provides detailed 
medRxiv preprint doi: https://doi.org/10.1101/2021.12.07.21267392; this version posted December 8, 2021. The copyright holder for this preprint (which was not certified by peer review) is the author/funder, who has granted medRxiv a license to display the preprint in perpetuity.

All rights reserved. No reuse allowed without permission.

142 information about qPCR analysis, including thermal cycles, qPCR cocktail compositions, and

143 primers.

144

\subsection{Preparing viruses for experiments with virus-spiked wastewater}

146 We determined the performance of the PGM-MBs method using influent wastewater spiked with

147 viruses propagated in vitro. These viruses are Tulane virus (TV, Caliciviridae, a viral surrogate

148 for human norovirus) (Yu et al., 2013), rotavirus OSU strain (RV, Reoviridae, ATCC VR-892),

149 adenovirus type 2 (AdV, Adenoviridae, ATCC VR-846), human coronavirus (NL63,

150 Coronaviridae), and porcine coronavirus (TGEV, Coronaviridae). We obtained TV from the

151 Cincinnati Children's Hospital Medical Center. We obtained NL63 strain from BEI sources (NR-

152 470). TGEV is a porcine enteric virus, and is in the same family as NL63 and SARS-CoV-2

153 (Coronaviridae). We received the TGEV from the Veterinary Diagnostic Laboratory at the

154 University of Illinois at Urbana-Champaign. Rotavirus strain OSU strain (RV, Reoviridae,

155 ATCC VR-892) and adenovirus type 2 (AdV, Adenoviridae, ATCC VR-846) were obtained from

156 the ATCC. Detailed information about propagation methods including culture media and

157 growing conditions is elaborated in Text S3. Plaque assays were used to determine titers of TV,

158 RV, AdV, and TGEV. TCID50 assays were used to quantify NL63 titers. MA104 (ATCC, CRL-

159 2378.1) was used as a host cell line for TV and RV plaque assay. A549 (ATCC; CCL-185), MK2

160 cells (ATCC, CCL-7), and ST cells (CRL-1746, ATCC) were used to determine virus titers of

161 AdV, NL63, and TGEV, respectively. Detailed information on virus titer determination is

162 summarized in Text S4.

163 
medRxiv preprint doi: https://doi.org/10.1101/2021.12.07.21267392; this version posted December 8, 2021. The copyright holder for this preprint (which was not certified by peer review) is the author/funder, who has granted medRxiv a license to display the preprint in perpetuity.

All rights reserved. No reuse allowed without permission.

\subsection{Collection of influent wastewater and local sewage samples for method} optimization and evaluation

We collected environmental samples from 10 locations from January to July 2021 (20 samples in total) to cover a variety of wastewate. We collected a 24-hour composite of influent wastewater on February 3rd, 2021, from the Urbana \& Champaign Sanitary District, IL, USA, a district that serves about 100,000 local residents. Because the bacteria present in the wastewater interfere with the plaque assays, a portion of the influent wastewater was filtered through a $0.22 \mu \mathrm{m}$ polyethersulfone membrane filter (S2GPT02RE, Millipore Sigma, USA), and the filtered influent wastewater was used for sensitivity and specificity experiments (Section 3.1, 3.2, 3.3, and 3.6). The filtrate was stored at $-80 \square$ until used. The filtrate was thawed and stored at $4 \square$ for less than two weeks, a time period where we conducted all experiments in this study.

Three-day composite sewage samples were collected from January to July 2020 from 10 different neighborhood-level sewersheds across Champaign County, IL, USA (Table S3). These sewage samples were stored at $4 \square$ for less than two weeks before being used to test the impact of the filtration process on performances of the PGM-MBs method (Section 3.4) and the tolerance of the PGM-MBs method to PCR inhibitors (Section 3.5). In addition, the SARS-CoV-2 concentration in these sewages were measured for a smaller aliquot of these samples kept at $-80 \square$ for less than a week and analyzed as soon as they were defrosted (Section 3.7). Information including sampling locations and dates was summarized in Table S3. 
$187 \mathrm{~mL}$ of filtered influent wastewater (Table S3). The initial genome copies spiked to wastewater 188 were about $10^{7} \mathrm{gc}$ for TV and NL63 and about $10^{8} \mathrm{gc}$ for RV, AdV, and TGEV. The wastewater 189 was serially diluted in 10-fold increments (four serial dilutions for TV and NL63 and five serial 190 dilutions for RV, AdV, and TGEV) and the three biological replicates were prepared. The results 191 from this experiment can be found in Section 3.2.

192 We conducted another experiment to compare the recovery efficiencies (RE) of the 193 PGM-MBs method by examining viral genome concentration or virus titer. For these 194 experiments, $10 \mu \mathrm{L}$ of virus (about $10^{4} \mathrm{PFU}$ of TV, RV, AdV, and TGEV, and $10^{3} \mathrm{TCID} 50$ of $195 \mathrm{NL63}$ ) and $10 \mu \mathrm{L}$ of $\mathrm{MgCl}_{2}$ (final concentrations of $50 \mathrm{mM}$ ) was added to $1 \mathrm{~mL}$ of six different 196 filtered sewage samples (Table S3). Viral genome concentrations and infectious virus titers in 197 the initial sewage samples were quantified. After that, we put $10 \mu \mathrm{L}$ of PGM-MBs to these 198 sewage samples. Then, we took the supernatant and quantified its genome concentrations and 199 virus titers. We assumed that the difference in viral genomes and virus titers between the initial 200 sewage and the supernatant is the recovered genomes and virus titers by the PGM-MBs method 201 (Eq. 1). Section 3.3 presents the results from this experiment.

\subsection{Tolerance for PCR inhibitors}

We conducted a set of experiments to understand the impact of solid particles on

207 performances (RE and tolerance to PCR inhibitors) of the PGM-MBs method. We chose 6 208 sewage samples collected from different sampling locations or times. These sewage samples 209 were left in a refrigerator at $4 \square$ for two hours without disturbance to mimic sedimentation. The 
210 liquid near the surface of these samples was used for two experiments. In the first experiment,

211 this liquid was used as it is. In the second experiment, this liquid was filtered by $0.22 \mu \mathrm{m}$ pore

212 size filters. Each of five viral species (about $10^{6} \mathrm{gc}$ ) was added to $10 \mathrm{~mL}$ of either the filtered or

213 the unfiltered samples before these samples were subjected to the PGM-MBs. The concentrations

214 of viral genomes in samples before and after the PGM-MBs method were quantified and the

215 recovery efficiencies were calculated. In addition, we tested the impact of solid particles as PCR

216 inhibitors. In these experiments, we used the same pairs of unfiltered and filtered samples

217 described above. Then, we applied the PGM-MBs method to the sewage samples, to which we

218 did not spike any viruses. After we obtained the final extracts from the PGM-MBs sample, we

219 spiked $1 \mu \mathrm{L}$ of TV genomes to $10 \mu \mathrm{L}$ of the final extracts. Because TV is a Rhesus monkey virus,

220 they are not expected in the sewage samples. The same number of TV genomes was added to

221 PCR inhibitor-free water (molecular biology grade water) as control samples. The results about

222 the impact of solid particles on the performances of the PGM-MBs method are presented in

223 Section 3.4.

224 We also tested tolerance of the PGM-MBs method to PCR inhibitors in environmental

225 samples. We collected 19 different sewage samples and 1 sample from lagoon (Table S3). We

226 also dissolved humic acid (41747, Alfa Aesar, USA), which was extracted by alkaline extraction

227 method from brown coal, to molecular biology grade water at a final concentration of $20 \mathrm{mg}$ C/L.

228 These 21 samples were filtered through $0.22 \mu \mathrm{m}$ membrane filters before being processed these

22921 samples with two different methods: a commercially available genome extraction kit (Viral

230 RNA Mini Kit) and the PGM-MBs method. We subjected $140 \mu \mathrm{L}$ of the samples to the Viral

231 RNA Mini Kit (QIAGEN, German) and obtained $60 \mu \mathrm{L}$ of the final solution. To test the PGM-

232 MBs method, we put $10 \mu \mathrm{L}$ of the PGM-MBs to $10 \mathrm{~mL}$ of the samples adjusted to $50 \mathrm{mM}$ of 
$233 \mathrm{MgCl}_{2}$ and $100 \mu \mathrm{L}$ of a final solution was obtained. Then, we spiked $1 \mu \mathrm{L}$ of $\mathrm{TV}$ genomes to 10

$234 \mu \mathrm{L}$ of the two types of final solutions (i.e., genome extraction kit and PGM-MBs method) and

235 molecular biology grade water as PCR inhibitor negative controls. The results on the tolerance of

236 the PGM-MBs to PCR inhibitors are presented in Section 3.5.

\subsection{Specificity of the PGM-MBs method}

239 We prepared three different solutions: molecular biology grade water, filtered influent

240 wastewater without spiking viruses, and filtered influent wastewater with the four different viral

241 species spiked. For example, for a TV specificity test, the other four virus species (RT, AdV,

242 NL63, and TGEV) were spiked into $10 \mathrm{~mL}$ of the filtered influent wastewater to test impact of

243 co-existing viral species on detection of TV genomes. Then, we applied the PGM-MBs method

244 to each of these three solutions and analyzed target virus concentrations in the final extracts from

245 the control wastewater and the four virus-spiked wastewater. All samples were categorized into

246 either positives (i.e., Ct values less than 40) or negatives (undetermined or $\mathrm{Ct}$ values higher than

247 40). The results of the specificity experiment can be found in Section 3.6.

248 We applied the PGM-MBs method and electronegative membrane filtration method to 50

$249 \mathrm{~mL}$ of 7 different sewage samples. The sewage samples were filtrated by $0.22 \mu \mathrm{m}$ membrane

250 filters and the filtrate was supplemented by the $\mathrm{MgCl}_{2}$ at a final concentration of $50 \mathrm{mM}$. We

251 added about $10^{5}$ gc of NL63 as a internal control. These samples were incubated at room

252 temperature for 30 minutes before processing them either by the PGM-MBs method or the

253 electronegative membrane filtration method. For the PGM-MBs method, we put $50 \mu \mathrm{L}$ of the

254 PGM-MBs to the $50 \mathrm{~mL}$ of samples. The electronegative membrane filtration started with

255 filtering the $50 \mathrm{~mL}$ of sewage samples through $0.45 \mu \mathrm{m}$ electronegative membranes. After that, 
256 the membrane filter was placed into a $5 \mathrm{~mL}$ tube (0030119487, Eppendorf, Germany). We put a

257 mixture of lysing buffer $(2800 \mu \mathrm{L})$ and RNA carrier $(28 \mu \mathrm{L})$ followed by 1-minute vortex, 15 -

258 minute shaking at $450 \mathrm{rpm}$, and subsequent 1-minute vortex. Section 3.7 presents the results of

259 the comparison between the PGM-MBs method and the electronegative membrane filtration

260 method.

\subsection{Statistical analysis}

263 Mann-Witney test was conducted to compare differences in recovered viral genomes depending

264 on different $\mathrm{MgCl}_{2}$ concentraions (Fig. 1A) and extraction method (i.e., heat denaturation

265 method and extraction kit; Fig. 1B). Paried sample t-test was performed to compare recovery

266 efficiencies determined either by genome concentration or virus titer (Fig. 5) and to compare

267 recovery efficiencies with filtered and unfiltered sewage samples (Fig. 6). There were no outliers

268 (i.e., all data for the paired t-test exist within a range from Q1-1.5IQR and Q3+1.5IQR). Also,

269 normalities of the differences between two data sets were checked by Shapiro-Wilk test. Two-

270 sample proportion test was conducted to compare two binomial proportions of $\mathrm{Ct}$ values less

271 than 40 from control wastewater and virus-spiked wastewater in Table 2. We added notes to

272 Table 2 showing if sample size (n) times proportion (p) is greater than 5, which is an assumption

273 for the two-sample proportion test. All statistical analysis was conducted by OriginPro $2019 \mathrm{~b}$. 


\section{Results}

\subsection{Optimization of the PGM-MBs method for efficient concentration of enteric}

\section{viruses in wastewater}

278 We tested $\mathrm{MgCl}_{2}$ concentration and genome extraction method to optimize the PGM-MBs

279 method. $\mathrm{MgCl}_{2}$ is known to reduce repulsive electrical double layer force of small particles such

280 as viruses in liquid (Gorrepati et al., 2010; Gutierrez and Nguyen, 2012), so it has been used to

281 improve the performance of adsorption-based virus concentration methods such as

282 electronegative membrane filtration method (Ahmed et al., 2020; LaTurner et al., 2021; Lu et al.,

283 2020). We varied $\mathrm{MgCl}_{2}$ concentrations of the influent wastewater from $0 \mathrm{mM}$ to $100 \mathrm{mM}$ to

284 find the optimum concentration for virus-PGM-MB interactions. Fig. 1A shows the amount of

285 viruses recovered by $\mathrm{PGM}-\mathrm{MBs}$ when different $\mathrm{MgCl}_{2}$ concentrations were used. With the

286 exception of TGEV, $\mathrm{MgCl}_{2}$ increased the amount of virus binding to PGM-MBs. For example,

287 the binding efficiency to PGM-MBs significantly increased for TV or NL63 as $\mathrm{MgCl}_{2}$

288 concentration increased until $10 \mathrm{mM}$ (Mann-Whitney test, $\mathrm{p}<0.05)$. The binding efficiencies of

$289 \mathrm{RV}$ or $\mathrm{AdV}$ to PGM-MBs became insignificantly different at 50 and $100 \mathrm{mM} \mathrm{MgCl}_{2}\left(\mathrm{Mann}^{-}\right.$

290 Whitney test, $\mathrm{p}<0.05)$. Therefore, $50 \mathrm{mM}$ was determined as the optimal concentration of $\mathrm{MgCl}_{2}$

291 for the PGM-MBs method.

292 Second, we established a heat denaturation method to release genomes from viruses

293 bound to PGM-MBs as an alternative to using nucleic acid extraction kits. This method only

294 requires the addition of proteinase $K$ followed by heating up at $95 \square$ for 10 minutes. Fig. 1B

295 presents the results obtained from two experiments, in which the PGM-MBs method was applied

296 to the spiked wastewater samples and the retrieved PGM-MBs were subjected to either an

297 extraction kit (Viral RNA Mini Kit, Qiagen) or the heat denaturation method. The RNA 
301 method.

302

303

304

305

306

307

308

309

310

311

312 Genome concentrations of the spiked viruses in the initial wastewater samples are plotted on the

$313 \mathrm{X}$ axis of Fig. 2. On the $\mathrm{Y}$ axis, we plotted the genome concentrations of the corresponding final

314 solutions after applying the PGM-MBs method. Linear correlations were obtained for all cases

$315\left(\mathrm{R}^{2}>0.97\right)$ as shown in Fig. 2. Based on these linear correlations, we determined recovery

Fig. 1. (A) Determination of the optimum $\mathrm{MgCl}_{2}$ concentration. The $y$-axis indicates the recovered viral genomes at different $\mathrm{MgCl}_{2}$ concentrations divided by the average number of viral genomes at $0 \mathrm{mM}$ of $\mathrm{MgCl}_{2}$. (B) Comparison between results obtained with Viral RNA Mini Kit and with the heat denaturation method. The y-axis represents the recovered viral genomes divided by average number of viral genomes by extraction kit. Statistical analysis of two groups of results were conducted by a non-parametric test (Mann-Whitney Test; *: p<0.05 and ns: no significant difference).

\subsection{Evaluation of the PGM-MBs method with spiked viruses}

(A)
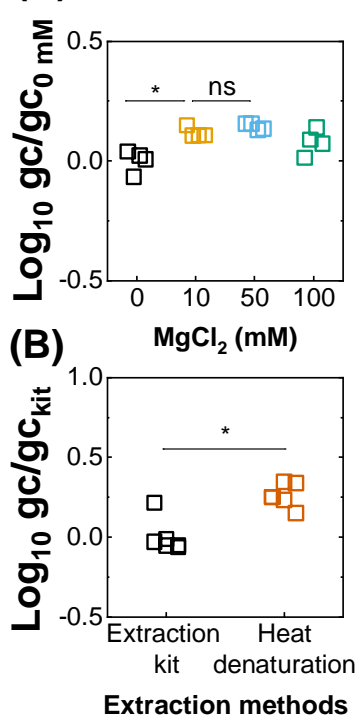

RV
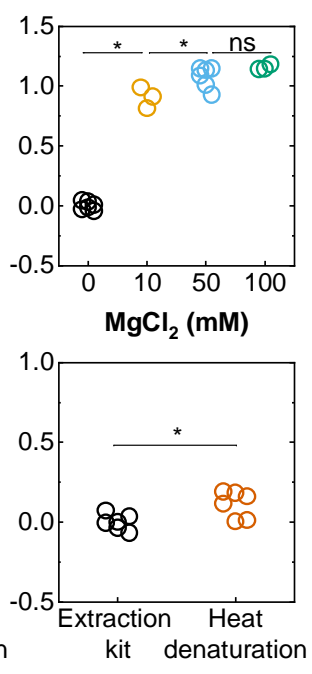

Estratatonomatese
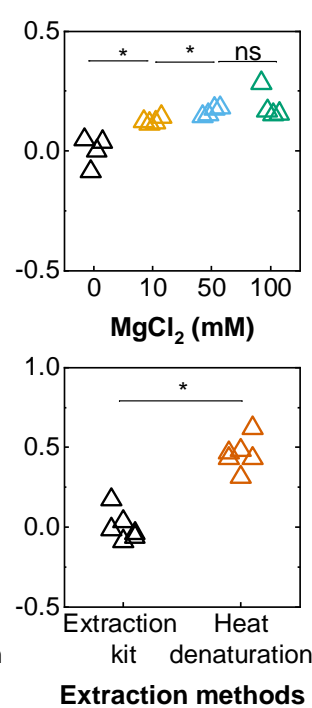

NL63
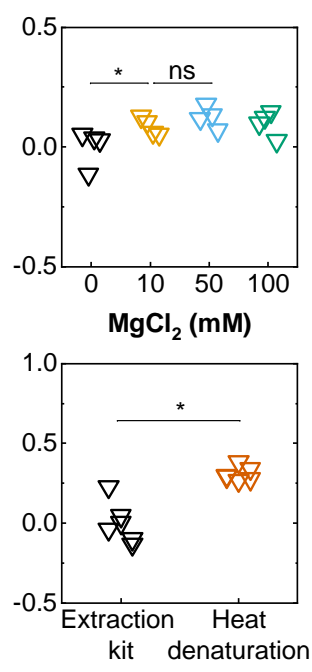

Extraction methods
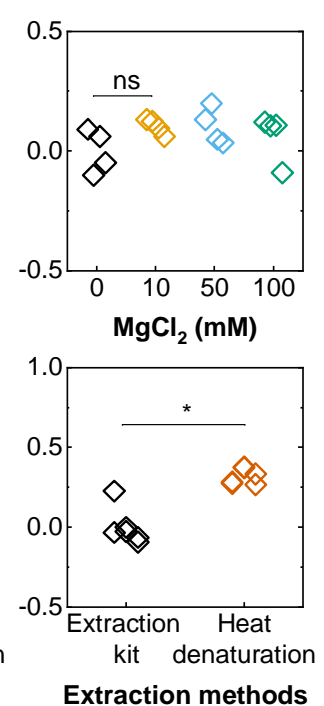
medRxiv preprint doi: https://doi.org/10.1101/2021.12.07.21267392; this version posted December 8, 2021. The copyright holder for this preprint (which was not certified by peer review) is the author/funder, who has granted medRxiv a license to display the preprint in perpetuity.

All rights reserved. No reuse allowed without permission.

316 efficiency (RE), concentration factor (CF), multiplication factor (MF), and LOQPGM-MBs as

317 shown in Eqs 2-4.

318

$R E=\frac{\text { The number of virus particles }}{\text { Final solution }}$

$C F=\frac{\text { Volume }_{\text {Final solution }}}{\text { Volume }_{\text {Initial solution }}}$

$M F=\frac{\text { Concentration }_{\text {final solution }}}{\text { Concentration }_{\text {initial solution }}}=\frac{R E}{C F}$

Fig. 2 Calibration curves showing the relationship between genome concentrations of initial

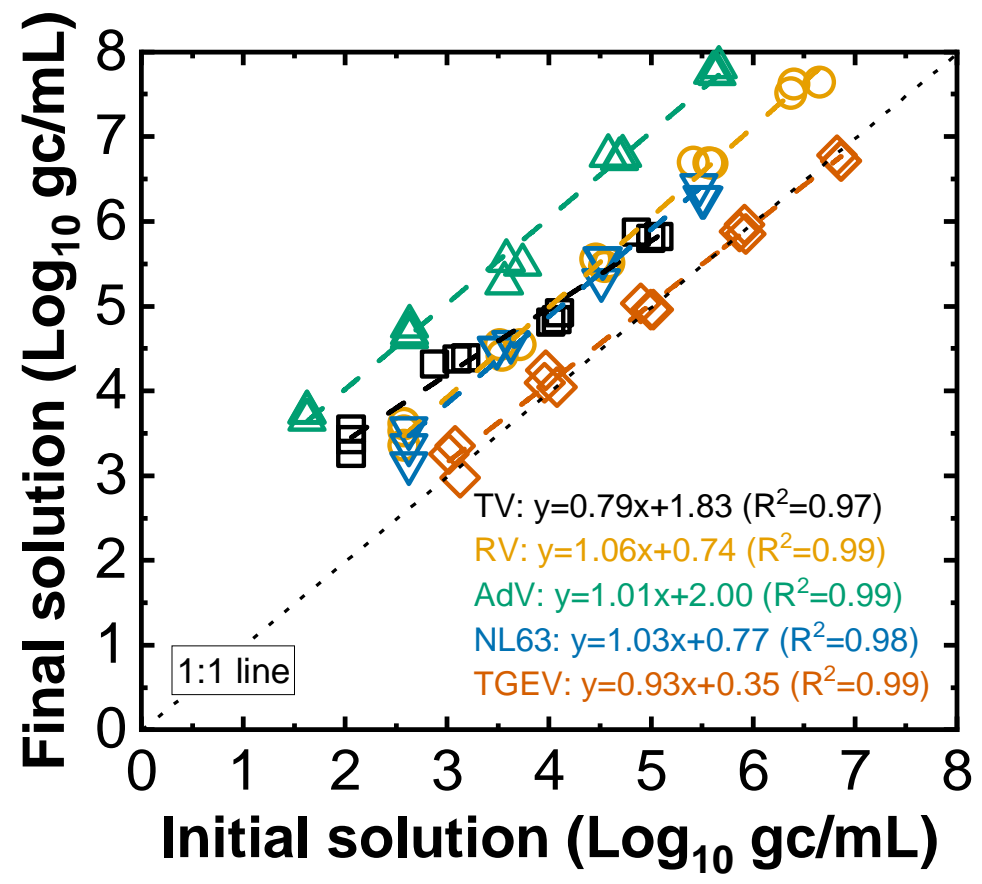
solutions and final solutions. Three biological replications were tested for each concentration.

328 for each viral species in Table 1. We found that the PGM-MBs method showed different

329 performances depending on testing viral species. For example, the REs ranged from 0.013

330 (TGEV) to 0.640 (AdV). The wide range of REs with different testing viruses were also reported 
331 by previous studies (Uchida et al., 2007; Ye et al., 2016). Since CF values were maintained

332 throughout the experiments to be 0.01 (i.e., $0.1 \mathrm{~mL}$ of final volume and $10 \mathrm{~mL}$ of initial volume),

333 MF values also showed a wide range from 1.3 (TGEV) to 64 (AdV). The MF values showed that

334 AdV could be concentrated 64 times, while TGEV was concentrated by 1.3 times. Regardless of

335 the viral species, the PGM-MBs method was able to concentrate enteric viruses from $10 \mathrm{~mL}$ of

336 wastewater.

LOQ is defined by the lowest genome concentrations that fulfill the following two conditions: 1) None of the replicates (e.g., nine qPCR samples from three biological replicates

339 and three technical replicates) is undetermined by qPCR or RT-qPCR analysis, and 2) coefficient

340 of variation for all replicates is less than 25\% (Forootan et al., 2017; Kralik and Ricchi, 2017). In

341 this study, $\mathrm{LOQ}_{\mathrm{F}}$ is LOQ of final solution obtained by the PGM-MBs method. On the other hand,

342 the LOQ ${ }_{\mathrm{PGM}-\mathrm{MB}}$ is the genome concentrations of initial solution whose final concentrations after

343 being concentrated by the PGM-MBs method becomes the LOQF. By definition, LOQPGM-MBs is

344 the lowest genome concentration of initial solution from Fig. 2. Table 1 shows the LOQ of the

345 PGM-MBs method for each viral species ranging from $10^{4.63}$ to $10^{6.08} \mathrm{gc} / \mathrm{L}$. These LOQ values

346 were comparable to the previously reported LOQs determined by 36 different methods for

347 SARS-CoV-2 surveillance (Pecson et al., 2021).

Table 1. The summary of the virus concentration experiment using the PGM-MBs method with $35010 \mathrm{~mL}$ of filtered influent wastewaters

\begin{tabular}{|c|c|c|c|c|}
\hline Viral species & RE & CF & MF & $\begin{array}{c}\text { LOQ of PGM-PMs } \\
\text { method }\left(\log _{\mathbf{1 0}} \mathbf{g c} / \mathbf{L}\right)\end{array}$ \\
\hline TV & $0.152 \pm 0.092$ & 0.01 & $15.2 \pm 9.2$ & 5.10 \\
\hline RV & $0.123 \pm 0.041$ & 0.01 & $12.3 \pm 4.1$ & 5.57 \\
\hline AdV & $0.640 \pm 0.166$ & 0.01 & $64.0 \pm 16.6$ & 4.63 \\
\hline
\end{tabular}




\begin{tabular}{|c|c|c|c|c|}
\hline NL63 & $0.103 \pm 0.023$ & 0.01 & $10.3 \pm 2.3$ & 5.62 \\
\hline TGEV & $0.013 \pm 0.005$ & 0.01 & $1.3 \pm 0.5$ & 6.08 \\
\hline
\end{tabular}

354 Philo et al., 2021; Randazzo et al., 2020; Ye et al., 2016). Since the previous publications used

355 different initial volumes, we calculated the MF values of PGM-MBs, which would be obtaind

356 with wastewater samples used previously. For this calculation, we derived the following Eqs 5-7.

357 Since LOQ $_{\mathrm{PGM}-\mathrm{MBs}}$ is one of the initial concentrations at a specific condition where its final 358 concentration is the $\mathrm{LOQ}_{\mathrm{F}}$, we can derive Eq. 5 from Eqs. 2-4.

$L O Q_{P G M-M B s}=\frac{1}{M F} \times L O Q_{F}=\frac{C F}{R E} \times L O Q_{F}=\frac{\text { Volume }_{\text {Final solution }}}{\text { Volume }_{\text {Initial solution }}} \times \frac{1}{R E} \times L O Q_{F}$

362 Eq. 5 shows that LOQPGM-MBs are inversely proportional to Volume Initial solution, $_{\text {, so }}$ the LOQ $\mathrm{PGM}_{\mathrm{PBs}}$

363 will be lowered as the volume of the initial solution increases if the other variables such as

$364 V_{\text {Volume }}$ Final solution, $L O Q_{F}$, and $R E$ remain constant as Volume Initial solution changes. Therefore, we

365 can reasonably assume that Volume $_{\text {Final solution }}$ and $L O Q_{F}$ will be maintained if the same virus

366 concentration method and quantification instruments are used. We also assumed RE is

367 maintained when the volume ratio of the PGM-MBs to the initial solution is fixed to $10 \mu \mathrm{L}$ to 10

368 mL. Therefore, we can derive Eqs. 6-7. 


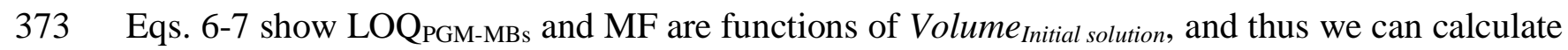

374 LOQ $_{\mathrm{PGM}-\mathrm{MBs}}$ and MF at different initial volumes such as 50, 200, and $1000 \mathrm{~mL}$ with LOQPGM-MBs

375 and MF values that were experimentally determined with the $10 \mathrm{~mL}$ of the initial solution (Table

376 S4).

377 We calculated the MF values of the PGM-MBs method with different initial volumes by

378 Eq. 7. These MF values are presented as the solid lines in Fig. 3. Open symbols represent the MF

379 of conventaionl virus concentration methods reported by previous studies (Ahmed et al., 2020;

380 LaTurner et al., 2021; Philo et al., 2021; Randazzo et al., 2020; Ye et al., 2016). These

381 previously reported MF values vary depending on virus concentration methods (direct extraction,

382 electronegative membrane, PEG, ultrafiltration, ultracentrifugation, and skimmed milk etc.) and

383 target viral species (BCoV, MHV, OC43, MgV, MS2, T3, and Phi6) (Table S5). Also, MF

384 values will be also affected by water matrices that were not reflected in this comparison.

385 Nevertheless, we found the PGM-MBs method presented higher MFs compared to the

386 conventional counterparts in general. Specifically, MF values of PGM-MBs for TGEV (the least

387 effective testing virus by the PGM-MBs method) were higher than 77 out of 99 MFs by 388 conventional virus concentration methods. 


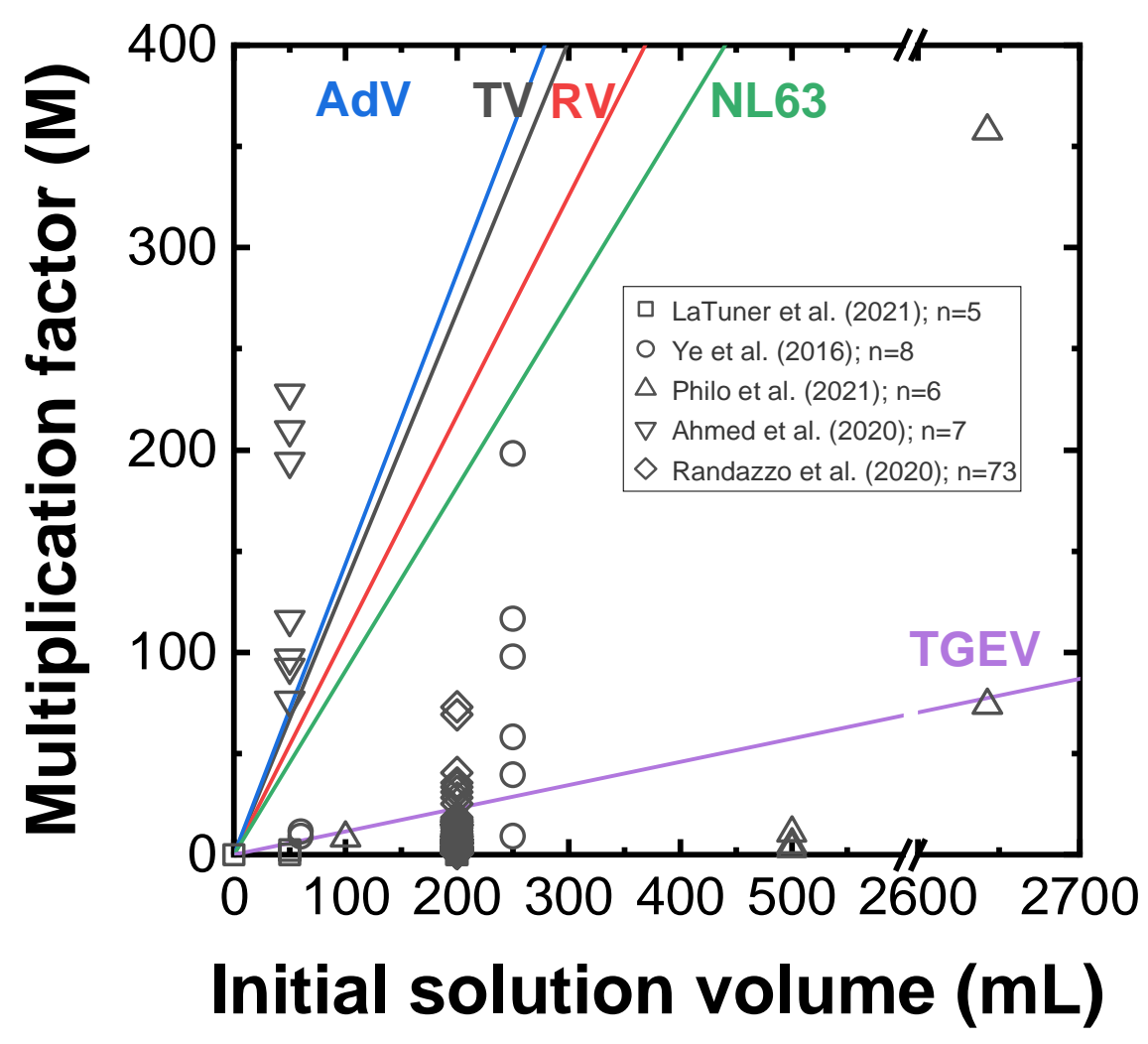

Fig. 3. Comparisons of multiplication factors (MF) of the PGM-MBs method to those from other studies (Ahmed et al., 2020; LaTurner et al., 2021; Philo et al., 2021; Randazzo et al., 2020; Ye et al., 2016). Solid lines are extrapolated MF from experimental results with $10 \mathrm{~mL}$ of influent wastewater using Eq. 7. Different colors for the solid lines represent MF for different viral species determined by the PGM-MBs method. Open symbols are MFs calculated from 99 virus concentration experiments reported by 5 different studies. Different shapes for the open symbols indicate each reference.

\subsection{Concentrating infectious viruses by the PGM-MBs method}

401 The quantification of infectious virus titers in the environment are essential to evaluate 402 accurately the risk posed to human health by viral pathogens (Haas et al., 2014). Thus, we 403 designed experiments that evaluated the ability of PGM-MBs to concentrate infectious enteric 404 viruses. The first experiment assessed if lab-grown viruses (TV, RV, AdV, NL63, and TGEV) 405 spiked in wastewater could determine the environmentally relevant concentrations of these 
medRxiv preprint doi: https://doi.org/10.1101/2021.12.07.21267392; this version posted December 8, 2021. The copyright holder for this preprint (which was not certified by peer review) is the author/funder, who has granted medRxiv a license to display the preprint in perpetuity.

All rights reserved. No reuse allowed without permission.

viruses. We serially diluted the lab-grown viruses to the filtered influent wastewater and

407 determined the genome concentrations and infectious virus titers. The slopes in Fig. 4 indicate

408 the ratio of genome concentrations to infectious virus titers in the virus-spiked wastewater. As

409 shown in Fig. 4, the genome concentrations are linearly correlated with the infectious virus titers

410 for each virus with slopes ranging from 0.87 to $1.20\left(\mathrm{R}^{2}>0.95\right)$ except for NL63 where only two

411 serial dilutions were measured because the initial NL63 titer was lower (about $10^{3} \mathrm{TCID} / \mathrm{mL}$ )

412 than the other species. This linear correlation is used to estimate the infectious virus titers at the

413 environment with genome concentrations.

414

415

416

417

418

419

420

421

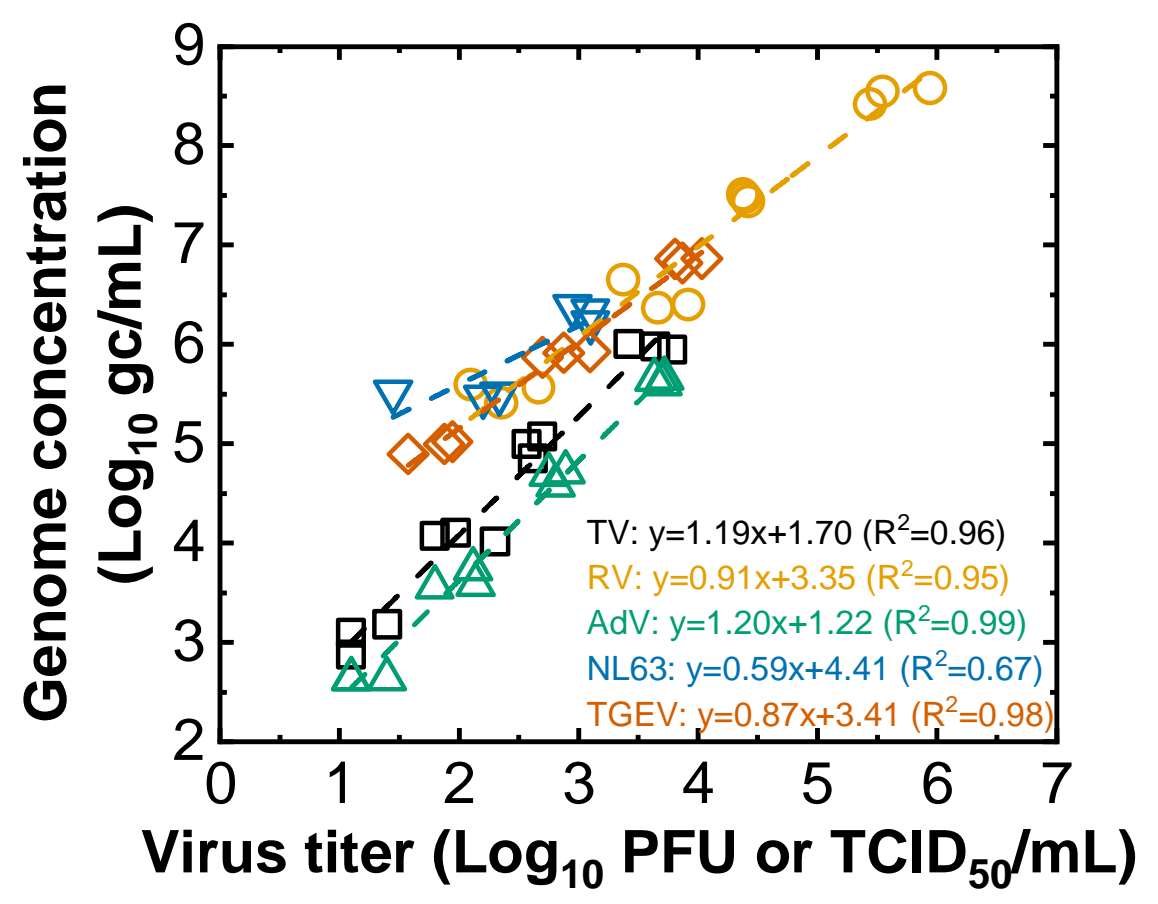

Fig. 4 Calibration curves showing the relationship between infectious virus titers and genome concentrations of the virus-spiked wastewaters $(n=3)$.

Next, we hypothesize that PGM-MBs have an intrinsic affinity to viruses with intact receptor-binding proteins that better represent infectious viruses than genome concentrations.

This hypothesis is tested by experiments in which either genome concentrations or virus titers 
422 were used to determine RE. We assumed the PGM-MBs has an affinity to infectious virus

423 particles if REs determined by virus titers are higher than those by genome concentrations. Fig. 5

424 shows that $\mathrm{RE}$ calculated by virus titers $\left(\mathrm{RE}_{\mathrm{titer}}\right)$ are significantly higher than those by genome

425 concentration $\left(\mathrm{RE}_{\text {genome }}\right)$ for the tested viral species (Paired sample t-test, $\mathrm{p}<0.05$ ) except for

$426 \mathrm{AdV}$ where both $\mathrm{RE}_{\text {titer }}$ and $\mathrm{RE}_{\text {genome }}$ were close to 1 (Paired sample t-test, $\mathrm{p}>0.05$ ). These results

427 support our hypothesis that PGM-MBs have a higher affinity for infectious virus particles

428 because the receptor-based approach excludes viruses whose receptor-binding proteins are

429 deficient. The affinity to infectous virus particles is a unique feature of this PGM-MBs method

430 considering the fact that conventional virus concentration methods such as ultracentrifugation,

431 ultrafiltration, PEG, and electronegative filtration showed rather lower $\mathrm{RE}_{\text {genome }}$ compared to

$432 \mathrm{RE}_{\text {titer }}$ (Rusiñol et al., 2020). Therefore, the recovered virus genomes by the PGM-MBs better

433 represents the risk stemming from the enteric viruses in the environment than those determined

434 by conventional counterparts.

435

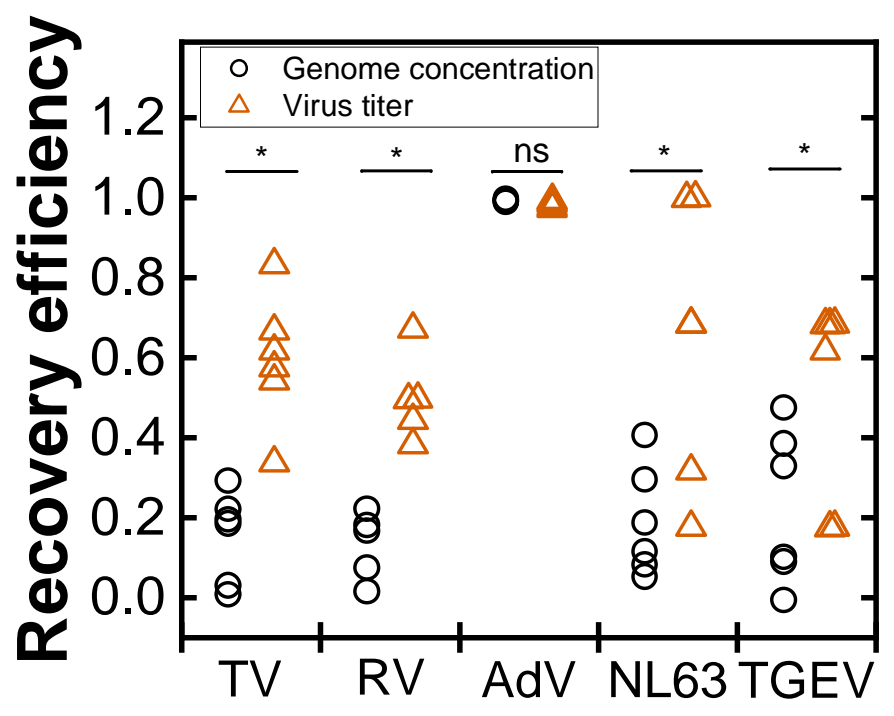


437 Fig. 5. Recovery efficiency of the PGM-MBs method in terms of virus gene copy and virus titer. 438 Statistical analyses were performed by a paired sample t-test (ns: no significant difference and *: $439 \mathrm{p}<0.05$ and $\mathrm{n}=6$ ).

\subsection{Performance of the PGM-MBs method for unfiltered environmental samples}

442 In the experiments described in 3.3, we removed bacterial cells that may interfere with the

443 plaque assay by filtering the samples with $0.22 \mu \mathrm{m}$ filters. Therefore, we designed another

444 experiments to confirm that the PGM-MBs method works for environmental samples without the

445 filtration process. We determined RE for each of the five viruses from the Filtered and Unfiltered

446 sewage samples (Fig. 6A). The paired sample t-test results showed that the differences between

447 the Filtered and the Unfiltered samples were not significant different except for RV ( $>>0.05)$.

448 This finding support that the presence of solid particles in the sewage samples did not

449 significantly affected performances of the PGM-MBs method. We also tested the impact of solid

450 particles as PCR inhibitors. Fig. 6B presented that $\Delta \mathrm{Ct}$ values for TV of the final solutions,

451 which were obtained from either Filtered or Unfiltered sewage samples, were less than 1 (one

452 sample t-test, $\mathrm{p}<0.05)$. This finding means that neglible inhibition impact, as suggested

453 previously (Gibson et al., 2012; Wu et al., 2018). Thus, the PGM-MBs method can minimize the 454 effect of PCR inhibitors regardless of the existence of solid particles in the unfiltered 455 environmental samples. 

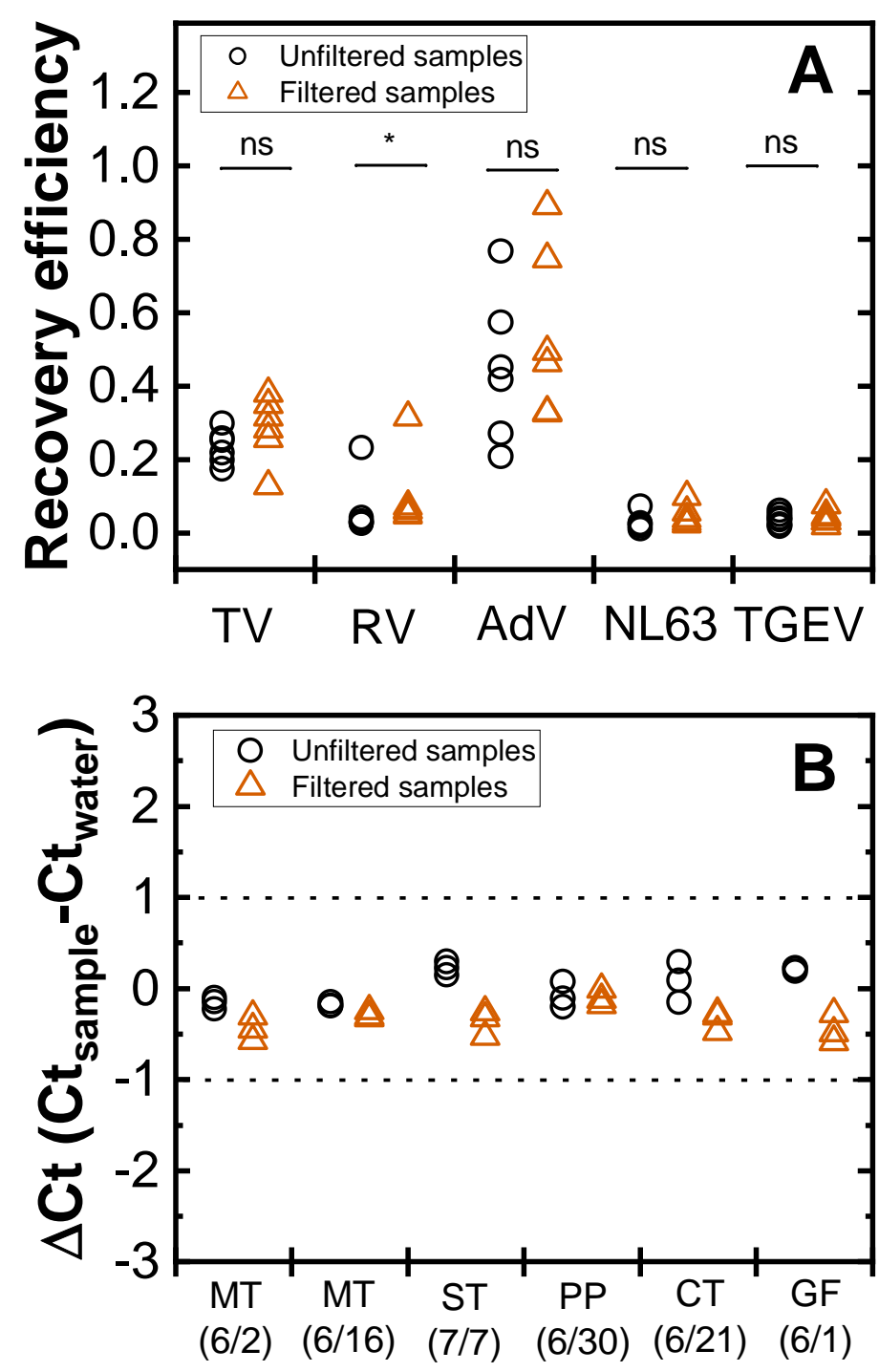

458 Fig. 6. Impact of solid particles to (A) recovery efficiency and (B) tolerance to PCR inhibitors of the PGM-MBs method. (A) Each of five viral species were spiked to both filtered and unfiltered samples. Recovery efficiencies of both filtered and unfiltered samples for each viral species were compared by paired sample t-test (ns: no significant difference, *: $\mathrm{p}<0.05$ and $n=6$ ). (B) Both filtered and unfiltered samples were subjected to the PGM-MBs method. TV genomes were spiked to final solutions of the PGM-MBs method and PCR inhibitor-free water (negative control). $\Delta \mathrm{Ct}$ values were calculated by subtracting $\mathrm{Ct}_{\text {water }}$ from $\mathrm{Ct}_{\text {sample. }}$. One sample $\mathrm{t}$-test was $\mathrm{n}=3$ ). 


\subsection{Evaluation of the PGM-MBs method for PCR inhibitors in environmental} samples

470 We designed experiments to test if the PGM-MBs method can reduce the PCR inhibitors from

471 the environmental samples. PCR inhibition was evaluated by comparing the $\Delta \mathrm{Ct}$ values for 21

472 different samples (Fig. 7). Out of the 21 samples, 19 samples have $\Delta \mathrm{Ct}$ obtained by either the kit

473 or PGM-MBs method is smaller than 1, so both the extraction kit and the PGM-MBs method 474 were capable of eliminating PCR inhibitors for these 19 samples. For these 19 samples, there 475 was no significant difference between $\Delta \mathrm{Ct}$ values of the two methods (paired sample t-test; $476 \mathrm{p}>0.05)$. On the other hand, both methods will require dilutions to avoid PCR inhibitors in the

477 lagoon sample and samples spiked with coal-based humic acid. However, additional 5-fold and 478 2-fold dilution were enough for the PGM-MBs method to reduce PCR inhibitors remaining in the 479 lagoon and humic acid samples, respectively. In contrast, those extra dilutions were not enough 480 for the extraction kit to reduce the inhibition. Our findings agree with a previous study showing 481 the PGM-MBs were less sensitive to the PCR inhibitors from fresh herbs and leafy vegetables 482 than using PEG method and commercial genome extraction kit (Suresh et al., 2019). Maher et al. 483 (2001) also demonstrated magnetic bead-based purification successfully eliminates PCR 484 inhibitors in the airborne environment. Therefore, we concluded that the PGM-MBs method is as 485 tolerant to PCR inhibitors in environmental samples as a commercial kit. 


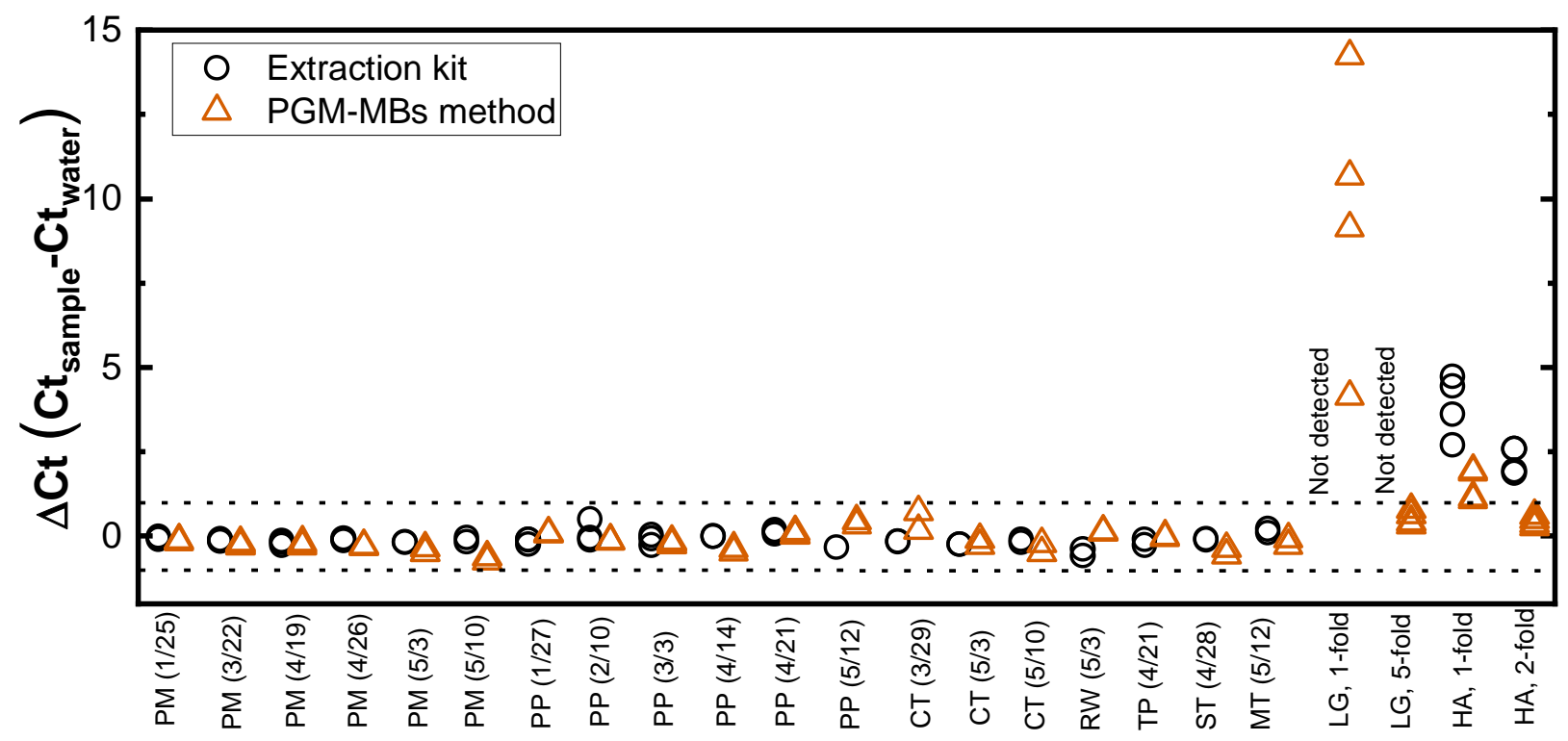

Fig. 7. Evaluation of a commercial genome extraction kit (Viral RNA Mini Kit, Qiagen) and the PGM-MBs method in reducing PCR inhibitors in 20 environmental samples (different sampling locations or dates) and $20 \mathrm{mg} / \mathrm{L}$ of humic acid dissolved water. Tulane virus was spiked to those 21 different samples that were treated by either the extraction kit or the PGM-MBs method as well as molecular biology grade water (PCR inhibitor negative control). Lagoon and humic acid samples were further diluted 5-, and 2-fold, respectively.

\subsection{Evaluation of PGM-MBs method for specificity}

496 Porcine gastric mucin consists of different types of receptors, so various viral species are

497 expected to bound when the PGM-MBs are applied to environmental samples (Larsson et al.,

498 2009; McGuckin et al., 2011). The numbers of targeted virions attached to the PGM-MBs may

499 be smaller than other virions which may also attach to the PGM-MBs. The attachment of these

500 untargeted viral species could result in false-positive amplifications (Jaroenlak et al., 2016;

501 Schrader et al., 2012; Tamariz et al., 2006). Therefore, we examined if the introduction of

502 various viruses to the PGM-MBs causes false positives for the genome of our interest.

504 showed no detected level of genomes for RV, AdV, NL63, and TGEV, indicating that viral 505 genomes did not originate from the PGM-MBs (Table 2). Second, analysis of PGM-MBs in 
506 influent wastewater showed a few positive samples for TV, AdV, NL63, and TGEV, but 20

507 cases out of $76(33 \%)$ for RV (Table 2). Because the primers used for our porcine RV targeted

508 the VP1 gene of rotavirus group A, the detection of human RV in the wastewater is possible. In

509 Silico analysis using Basic Local Alignment Search Tool (BLAST) indeed confirmed that the

510 forward and reverse primers match 100\% to human RVs (GenBank ID:LC389885.1 and

511 ID:JQ715640.1, respectively). Human RV has been found in wastewater regardless of seasons

512 (Atabakhsh et al., 2019; Ibrahim et al., 2016). Nevertheless, the proportion of RV positive

513 samples from the influent wastewater were not significantly different from those from the virus-

514 spiked wastewater (two sample proportion test; $\mathrm{p}>0.05$ ) (Table 2). Ct values of pooled positive

515 samples also did not show significant difference between the influent wastewater and the virus-

516 spiked wastewater (two sample t-test; $\mathrm{p}>0.05$ ). Considering the outweighing amount of the

517 spiking viruses ( $\mathrm{Ct}$ values ranging from 14 to 23 ) over the detected $\mathrm{Ct}$ values (about 35), we

518 concluded that different types of viruses collected from the wastewater by the PGM-MBs

519 method would not significantly affect the detection of target viruses. 
Table 2. Specificity tests for the PGM-MBs method.

\begin{tabular}{|l|l|l|l|l|l|}
\hline \multirow{2}{*}{$\begin{array}{l}\text { Positivity rate (for each viral } \\
\text { species) or Ct values (for sum of the } \\
\text { five viral species) }\end{array}$} & \multicolumn{3}{|c|}{ Solution types } & \multirow{2}{*}{$\begin{array}{l}\text { Statistical } \\
\text { analysis }\end{array}$} \\
\cline { 3 - 6 } & TV & Distilled Water & Wastewater & $\begin{array}{l}\text { Virus spiked } \\
\text { Wastewater }\end{array}$ & \\
\hline \multirow{4}{*}{ Viral species } & RV & $0 / 30(0 \%)^{2)}$ & $1 / 30(3.3 \%)$ & $3 / 39(7.7 \%)$ & N.A. ${ }^{3)}$ \\
\cline { 2 - 6 } & AdV & $0 / 35(0 \%)$ & $20 / 76(26.3 \%)$ & $18 / 54(33.3 \%)$ & p >0.05 ${ }^{4)}$ \\
\cline { 2 - 6 } & NL63 & $0 / 40(0 \%)$ & $3 / 30(10.0 \%)$ & $2 / 30(6.7 \%)$ & N.A. \\
\cline { 2 - 6 } & TGEV & $0 / 30(0 \%)$ & $2 / 36(5.6 \%)$ & $4 / 36(11.1 \%)$ & N.A. \\
\hline Pooled positive samples & $0 / 40(\%)$ & $2 / 30(6.7 \%)$ & $2 / 30(6.7 \%)$ & N.A. \\
\hline
\end{tabular}

1) The spiked virus shows Ct values of 19.3, 22.5, 14.6, 21.2, and 23.0 for TV, RV, AdV, NL63, and TGEV, respectively.

2) The number of positive samples/total samples was presented with positivity rate in parentheses. At least five molecular replicates and six technical replicates $(n>30)$ were measured by the qPCR.

3) Not applicable. Group of data does not satisfy the assumptions for the two-sample proportion test (i.e., $\mathrm{np}<5$ ).

4) Positivity rates of wastewater and virus spiked wastewater were analyzed by the twosample proportion test.

5) All the positive $\mathrm{Ct}$ values regardless of the viral species were pooled, and an average was presented with a standard deviation.

6) Two sample t-test compared the $\mathrm{Ct}$ values of wastewater and virus spiked wastewater

\subsection{Application of the PGM-MBs method for SARS-CoV-2 surveillance}

We applied the electronegative membrane filtration method and the PGM-MBs methods in parallel for the SARS-CoV-2 surveillance with local sewages. The electronegative membrane filtration method represented conventional virus concentration methods here because of its high recovery efficiency (Ahmed et al., 2020; LaTurner et al., 2021; Lu et al., 2020). Seven different sewage samples, which tested positive for SARS-CoV-2 by either the filtration or the PGM-MBs method, were used for the comparison. To ensure qualities of the virus concentration processes, we spiked NL63, which recognizes the same receptors (ACE2) as SARS-CoV-2 (Rawat et al., 2021), to the sewage samples as an internal control. All the data reported showed higher than $1.0 \%$ 
545 of NL63 recovery efficiency. We found that NL63 recovery efficiencies for the filtration and the

546 PGM-MBs method were normally distributed (Shapiro-Wilk test, $\mathrm{p}>0.05$ ) in wide ranges from

5471.4 to $18.6 \%$ (Fig. S4). The wide range of recovery efficiencies were also reported elsewhere

548 (Randazzo et al., 2020), and this is probably because the two methods basically collect viral

549 genomes through virus adsorption to their media (i.e., electronegative membrane filter and the

550 PGM-MBs), which depends on the water characteristics ( $\mathrm{pH}$, ionic strength, or competing

551 substances) (Gutierrez and Nguyen, 2012). The NL63 recovery efficiencies by the

552 electronegative membrane filtration and the PGM-MBs method were not significantly different

553 (paired sample t-test, p>0.05). We measured the N1 gene of SARS-CoV-2 (Nalla et al., 2020),

554 and presented three technical replicates of $\mathrm{Ct}$ values, instead of concentrations, because most of

555 the samples showed N1 gene concentrations below LOQ (Table 3). The Ct values for N1 gene

556 were not significantly different between the two methods (paired sample t-test $\mathrm{p}>0.05$ ).

557 Therefore, we concluded the PGM-MBs method can be applied for monitoring SARS-CoV-2 in 558 wastewater. 
medRxiv preprint doi: https://doi.org/10.1101/2021.12.07.21267392; this version posted December 8, 2021. The copyright holder for this preprint (which was not certified by peer review) is the author/funder, who has granted medRxiv a license to display the preprint in perpetuity.

All rights reserved. No reuse allowed without permission.

561 Table 3. Application of the PGM-MBs method for wastewater-based SARS-CoV-2 surveillance

\begin{tabular}{|c|c|c|c|c|c|c|c|c|}
\hline \multirow{3}{*}{\begin{tabular}{|l} 
Sample $^{1)}$ \\
RW (6/1)
\end{tabular}} & \multicolumn{2}{|c|}{$\begin{array}{l}\text { NL63 recovery (\%) (multiplication } \\
\text { factor) }\end{array}$} & \multicolumn{6}{|c|}{$\mathrm{Ct}$ values for $\mathrm{N} 1$ gene } \\
\hline & \multirow{2}{*}{$\begin{array}{l}\begin{array}{l}\text { Electronegative } \\
\text { membrane } \\
\text { filtration }\end{array} \\
2.5(21)\end{array}$} & \multirow{2}{*}{$\begin{array}{l}\text { PGM-MBs } \\
6.1(30)\end{array}$} & \multicolumn{3}{|c|}{$\begin{array}{l}\text { Electronegative } \\
\text { membrane filtration }\end{array}$} & \multicolumn{3}{|c|}{ PGM-MBs } \\
\hline & & & $32.8^{1)}$ & 33.2 & 34.2 & 33.9 & 33.1 & 33.4 \\
\hline WS $(6 / 1)$ & $2.0(17)$ & $7.5(38)$ & 36.7 & 35.0 & 36.3 & 36.4 & 34.9 & 36.4 \\
\hline $\operatorname{MT}(6 / 9)$ & $1.7(14)$ & $1.4(7)$ & 34.1 & 33.6 & 34.0 & 37.2 & 36.5 & 36.4 \\
\hline $\mathrm{PM}(6 / 13)$ & $9.7(81)$ & $13.4(67)$ & 35.9 & 37.8 & $\mathrm{U}^{2)}$ & 35.9 & 36.0 & 37.0 \\
\hline $\operatorname{PM}(6 / 21)$ & $12.9(107)$ & $18.6(93)$ & 36.2 & 38.0 & $\mathrm{U}$ & 34.9 & 36.9 & 36.6 \\
\hline ST $(6 / 2)$ & $7.4(64)$ & 3.7 (19) & 44.1 & $\mathrm{U}$ & $\mathrm{U}$ & 38.2 & $\mathrm{U}$ & $\mathrm{U}$ \\
\hline ST (7/7) & $5.5(46)$ & 3.9 (19) & 37.6 & 35.6 & $\mathrm{U}$ & 36.9 & 36.8 & $\mathrm{U}$ \\
\hline
\end{tabular}

1) Numbers in paranthesis indicate collected month/date.

2) Whichever shaded data set between electronegative membrane filtration and PGM-MBs for each sample indicates lower average $\mathrm{Ct}$ values.

3) U stands for undetermined samples until 45 PCR cycles.

4. Discussion

\subsection{The PGM-MBs method proves suitability for wastewater-based epidemiology}

569 High throughput became an important factor for successful WBE because a fast turnaround for

570 analyzing virus concentration of wastewater is critical (Betancourt et al., 2021; Zhu et al., 2021).

571 The adaptability to high throughput instruments, low price, and a short operational time should

572 be considered to evaluate virus concentration methods. Using magnetic beads and heat

573 denaturation for collecting viruses and extracting viral genomes, respectively, allow the PGM-

574 MBs method to satisfy those three requirements. Karthikeyan et al. (2021) demonstrated that a

575 magnetic-bead-based approach could be implemented for an automated nucleic acid purification

576 system (Thermo Fisher Scientific, USA), which enabled high throughput analysis (96 samples

577 per run). In addition, using the PGM-MBs will further lower the cost for WBE. For example, 
578 consumables for the production of the $10 \mu \mathrm{L}$ PGM-MBs (10 mL wastewater sample analysis)

579 cost 0.413 USD (Table S6). Essential materials for this method, including magnetic beads,

580 mucin, magnets, and proteinase $\mathrm{K}$ are not proprietary. Also, the entire process for the PGM-MBs

581 method only takes less than 3 hours, including concentrating viruses (30 minutes), extracting

582 genomes (10 minutes), and quantifying viral genomes (90 minutes), which is much shorter than

583 conventional virus concentration methods (Cervantes-Avilés et al., 2021). For example,

584 ultrafiltration (Haramoto et al., 2020), skimmed milk flocculation (Guerrero-Latorre et al., 2020),

585 and PEG precipitation (La Rosa et al., 2020b) took 5.2, 9.6, and 12.8 hours only for a virus

586 concentration step, respectively. Taken together, the PGM-MBs method is expected to be scaled

587 up for high throughput analysis.

\subsection{Performance of PGM-MBs method is comparable to or better than} conventional virus concentration methods

591 We made two comparisons between PGM-MBs and conventional counterparts to evaluate the

592 performances in concentrating viruses from environmental samples. First, we systematically

593 characterize the performances of PGM-MBs method with five model viruses and wastewater.

594 Because there are various virus concentration methods, we could not test all these conventional

595 methods in the same experimental conditions as the experiments for the PGM-MBs method.

596 Instead, we compared MF of the PGM-MBs method to those reported by previous studies. Note

597 that we chose MF over LOQ for the comparison because LOQ depends on instruments (e.g., 598 ddPCR versus qPCR) (Falzone et al., 2020; Park et al., 2021) and qPCR methods (e.g., SYBR

599 versus Taqman method) (Fuchs Wightman et al., 2021) while MF focuses only on the increase in 600 viral genome concentrations by virus concentration methods. Thus, although we could compare 
601 the PGM-MBs method with various experiments using different virus concentrations (Fig. 3), we

602 could not directly compare the results on the same experimental conditions. To compensate for

603 this limitation, we applied the PGM-MBs method and electronegative membrane filtration

604 method, which is one of the most efficient virus conventional methods (Ahmed et al., 2020;

605 LaTurner et al., 2021; Lu et al., 2020) for SARS-CoV-2 concentration under the same

606 experimental conditions (Table 3). Given the findings from Fig. 3 and Table 3, we concluded

607 that the PGM-MBs method is comparable to or better than conventional methods to concentrate

608 various enteric viruses, including SARS-CoV-2 from environmental samples.

\section{Conclusions}

This study first introduced a novel approach to concentrate enteric viruses from the

612 environment using porcine gastric mucin-conjugated magnetic beads (PGM-MBs). This novel

613 method is simple, fast, affordable, and comparable with conventional methods. The optimized

614 PGM-MBs method takes less than 3 hours from virus concentration to genome quantification

615 and costs less than 0.5 USD for $10 \mathrm{~mL}$ volume of sample without expensive instruments such as

616 an ultracentrifuge. We systematically demonstrated that the performance of PGM-MBs method

617 is comparable to or better than conventional methods to concentrate various enteric viruses,

618 including SARS-CoV-2, from environmental samples. We also discovered that the PGM-MBs

619 method is robust to environmental samples, which features the existence of different viral species

620 and PCR inhibitors. Taken all together, we concluded that the PGM-MBs method can readily be

621 used for urgent SARS-CoV-2 surveillance to cope with the current COVID-19 pandemic or

622 monitoring other enteric viruses for better public health management. 
medRxiv preprint doi: https://doi.org/10.1101/2021.12.07.21267392; this version posted December 8, 2021. The copyright holder for this preprint (which was not certified by peer review) is the author/funder, who has granted medRxiv a license to display the preprint in perpetuity.

All rights reserved. No reuse allowed without permission.

\section{Acknowledgement}

625 This project is funded by the Grainger College of Engineering and the JUMP-ARCHES program

626 of OSF Healthcare in conjunction with the University of Illinois. The Human coronavirus NL63

627 strain (NR-470) was obtained through BEI Resources, NIAID. We thank Mr. Bruce Rabe at

628 Urbana \& Champaign Sanitary District for providing us with influent wastewater. We also

629 acknowledge Bill Brown for sampling site selection, Hayden Wennerdahl, Kip Stevenson, Dr.

630 Laura Keefer and Dr. Schmidt for sampling deployment, and Yuqing Mao, Aijia Zhou, Matthew

631 Robert Loula, Aashna Patra, Kristin Joy Anderson, Mikayla Diedrick, Hubert Lyu, Hamza

632 Elmahi Mohamed, Jad R Karajeh, Runsen Ning, Rui Fu, Kate O’Brien for sewage sampling and

633 processing.

634

635

636 


\section{Reference}

Afolayan, O.T., Webb, C.C., Cannon, J.L., 2016. Evaluation of a Porcine Gastric Mucin and RNase A Assay for the Discrimination of Infectious and Non-infectious GI.1 and GII.4 Norovirus Following Thermal, Ethanol, or Levulinic Acid Plus Sodium Dodecyl Sulfate Treatments. Food Environ. Virol. 8, 70-78. https://doi.org/10.1007/s12560-015-9219-z Ahmed, W., Bertsch, P.M., Bivins, A., Bibby, K., Farkas, K., Gathercole, A., Haramoto, E., Gyawali, P., Korajkic, A., McMinn, B.R., Mueller, J.F., Simpson, S.L., Smith, W.J.M., Symonds, E.M., Thomas, K. V., Verhagen, R., Kitajima, M., 2020. Comparison of virus concentration methods for the RT-qPCR-based recovery of murine hepatitis virus, a surrogate for SARS-CoV-2 from untreated wastewater. Sci. Total Environ. 739, 139960. https://doi.org/10.1016/J.SCITOTENV.2020.139960

Ahmed, W., Tscharke, B., Bertsch, P.M., Bibby, K., Bivins, A., Choi, P., Clarke, L., Dwyer, J., Edson, J., Nguyen, T.M.H., O'Brien, J.W., Simpson, S.L., Sherman, P., Thomas, K. V., Verhagen, R., Zaugg, J., Mueller, J.F., 2021. SARS-CoV-2 RNA monitoring in wastewater as a potential early warning system for COVID-19 transmission in the community: A temporal case study. Sci. Total Environ. 761, 144216. https://doi.org/10.1016/J.SCITOTENV.2020.144216

Albinana-Gimenez, N., Clemente-Casares, P., Bofill-Mas, S., Hundesa, A., Ribas, F., Girones, R., 2006. Distribution of Human Polyoma- viruses, Adenoviruses, and Hepatitis E Virus in the Environment and in a Drinking-Water Treatment Plant†. Environ. Sci. Technol. 40, 74167422. https://doi.org/10.1021/ES060343I

Araud, E., Shisler, J.L., Nguyen, T.H., 2018. Inactivation Mechanisms of Human and Animal Rotaviruses by Solar UVA and Visible Light. Environ. Sci. Technol. 52, 5682-5690. https://doi.org/10.1021/acs.est.7b06562

Atabakhsh, P., Kargar, M., Doosti, A., 2019. Molecular detection and genotyping of group A rotavirus in two wastewater treatment plants, Iran. Brazilian J. Microbiol. 2019511 51, 197-203. https://doi.org/10.1007/S42770-019-00131-0

Betancourt, W.Q., Schmitz, B.W., Innes, G.K., Prasek, S.M., Pogreba Brown, K.M., Stark, E.R., Foster, A.R., Sprissler, R.S., Harris, D.T., Sherchan, S.P., Gerba, C.P., Pepper, I.L., 2021. COVID-19 containment on a college campus via wastewater-based epidemiology, targeted clinical testing and an intervention. Sci. Total Environ. 779, 146408. https://doi.org/10.1016/J.SCITOTENV.2021.146408

Binder, A.M., Biggs, H.M., Haynes, A.K., Chommanard, C., Lu, X., Erdman, D.D., Watson, J.T., Gerber, S.I., 2017. Human Adenovirus Surveillance - United States, 2003-2016. MMWR. Morb. Mortal. Wkly. Rep. 66, 1039. https://doi.org/10.15585/MMWR.MM6639A2

Bustin, S.A., Benes, V., Garson, J.A., Hellemans, J., Huggett, J., Kubista, M., Mueller, R., Nolan, T., Pfaffl, M.W., Shipley, G.L., Vandesompele, J., Wittwer, C.T., 2009. The MIQE guidelines: Minimum information for publication of quantitative real-time PCR experiments. Clin. Chem. 55, 611-622. https://doi.org/10.1373/clinchem.2008.112797

Cervantes-Avilés, P., Moreno-Andrade, I., Carrillo-Reyes, J., 2021. Approaches applied to detect SARS-CoV-2 in wastewater and perspectives post-COVID-19. J. Water Process Eng. 40, 101947. https://doi.org/10.1016/J.JWPE.2021.101947

Falzone, L., Musso, N., Gattuso, G., Bongiorno, D., Palermo, C.I., Scalia, G., Libra, M., Stefani, S., 2020. Sensitivity assessment of droplet digital PCR for SARS-CoV-2 detection. Int. J. Mol. Med. 46, 957-964. https://doi.org/10.3892/IJMM.2020.4673/HTML 
682

683

684

685

686

687

688

689

690

691

692

693

694

695

696

697

698

699

700

701

702

703

704

705

706

707

708

709

710

711

712

713

714

715

716

717

718

719

720

721

722

723

724

725

726

727

Fielding, B.C., 2011. Human coronavirus NL63: a clinically important virus? Future Microbiol. 6, 153-159. https://doi.org/10.2217/FMB.10.166

Forootan, A., Sjöback, R., Björkman, J., Sjögreen, B., Linz, L., Kubista, M., 2017. Methods to determine limit of detection and limit of quantification in quantitative real-time PCR (qPCR). Biomol. Detect. Quantif. 12, 1. https://doi.org/10.1016/J.BDQ.2017.04.001

Fuchs Wightman, F., Godoy Herz, M.A., Muñoz, J.C., Stigliano, J.N., Bragado, L., Moreno, N.N., Palavecino, M., Servi, L., Cabrerizo, G., Clemente, J., Avaro, M., Pontoriero, A., Benedetti, E., Baumeister, E., Rudolf, F., Remes Lenicov, F., Garcia, C., Buggiano, V., Kornblihtt, A.R., Srebrow, A., de la Mata, M., Muñoz, M.J., Schor, I.E., Petrillo, E., 2021. A DNA intercalating dye-based RT-qPCR alternative to diagnose SARS-CoV-2. RNA Biol. https://doi.org/10.1080/15476286.2021.1926648/SUPPL_FILE/KRNB_A_1926648_SM78 08.ZIP

Fuzawa, M., Araud, E., Li, J., Shisler, J.L., Nguyen, T.H., 2019. Free Chlorine Disinfection Mechanisms of Rotaviruses and Human Norovirus Surrogate Tulane Virus Attached to Fresh Produce Surfaces. Environ. Sci. Technol. 53, 11999-12006. https://doi.org/10.1021/acs.est.9b03461

Gibas, C., Lambirth, K., Mittal, N., Juel, M.A.I., Barua, V.B., Roppolo Brazell, L., Hinton, K., Lontai, J., Stark, N., Young, I., Quach, C., Russ, M., Kauer, J., Nicolosi, B., Chen, D., Akella, S., Tang, W., Schlueter, J., Munir, M., 2021. Implementing building-level SARSCoV-2 wastewater surveillance on a university campus. Sci. Total Environ. 782, 146749. https://doi.org/10.1016/J.SCITOTENV.2021.146749

Gibson, K.E., Schwab, K.J., Spencer, S.K., Borchardt, M.A., 2012. Measuring and mitigating inhibition during quantitative real time PCR analysis of viral nucleic acid extracts from large-volume environmental water samples. Water Res. 46, 4281-4291. https://doi.org/10.1016/J.WATRES.2012.04.030

Gorrepati, E.A., Wongthahan, P., Raha, S., Fogler, H.S., 2010. Silica precipitation in acidic solutions: Mechanism, pH effect, and salt effect. Langmuir 26, 10467-10474. https://doi.org/10.1021/LA904685X/SUPPL_FILE/LA904685X_SI_001.PDF

Guerrero-Latorre, L., Ballesteros, I., Villacrés-Granda, I., Granda, M.G., Freire-Paspuel, B., Ríos-Touma, B., 2020. SARS-CoV-2 in river water: Implications in low sanitation countries. Sci. Total Environ. 743, 140832. https://doi.org/10.1016/J.SCITOTENV.2020.140832

Gutierrez, L., Nguyen, T.H., 2012. Interactions between rotavirus and Suwannee River organic matter: Aggregation, deposition, and adhesion force measurement. Environ. Sci. Technol. $46,8705-8713$. https://doi.org/10.1021/ES301336U/SUPPL_FILE/ES301336U_SI_001.PDF

Haas, C.N., Rose, J.B., Gerba, C.P., 2014. Quantitative Microbial Risk Assessment. John Wiley \& Sons.

Haramoto, E., Kitajima, M., Hata, A., Torrey, J.R., Masago, Y., Sano, D., Katayama, H., 2018. A review on recent progress in the detection methods and prevalence of human enteric viruses in water. Water Res. 135, 168-186. https://doi.org/10.1016/J.WATRES.2018.02.004

Haramoto, E., Malla, B., Thakali, O., Kitajima, M., 2020. First environmental surveillance for the presence of SARS-CoV-2 RNA in wastewater and river water in Japan. Sci. Total Environ. 737, 140405. https://doi.org/10.1016/J.SCITOTENV.2020.140405

Harris-Lovett, S., Nelson, K.L., Beamer, P., Bischel, H.N., Bivins, A., Bruder, A., Butler, C., Camenisch, T.D., De Long, S.K., Karthikeyan, S., Larsen, D.A., Meierdiercks, K., Mouser, P.J., Pagsuyoin, S., Prasek, S.M., Radniecki, T.S., Ram, J.L., Keith Roper, D., Safford, H., 
Sherchan, S.P., Shuster, W., Stalder, T., Wheeler, R.T., Korfmacher, K.S., 2021. Wastewater Surveillance for SARS-CoV-2 on College Campuses: Initial Efforts, Lessons Learned, and Research Needs. Int. J. Environ. Res. Public Health 18. https://doi.org/10.3390/IJERPH18094455

Hart, O.E., Halden, R.U., 2020. Computational analysis of SARS-CoV-2/COVID-19 surveillance by wastewater-based epidemiology locally and globally: Feasibility, economy, opportunities and challenges. Sci. Total Environ. 730, 138875. https://doi.org/10.1016/J.SCITOTENV.2020.138875

Hu, Zhiliang, Song, C., Xu, C., Jin, G., Chen, Y., Xu, X., Ma, H., Chen, W., Lin, Y., Zheng, Y., Wang, J., Hu, Zhibin, Yi, Y., Shen, H., 2020. Clinical characteristics of 24 asymptomatic infections with COVID-19 screened among close contacts in Nanjing, China. Sci. China Life Sci. 63, 706-711. https://doi.org/10.1007/s11427-020-1661-4

Ibrahim, C., Cherif, N., Hammami, S., Pothier, P., Hassen, A., 2016. Quantification and Genotyping of Rotavirus A within Two Wastewater Treatment Processes. CLEAN - Soil, Air, Water 44, 393-401. https://doi.org/10.1002/CLEN.201400588

Jafferali, M.H., Khatami, K., Atasoy, M., Birgersson, M., Williams, C., Cetecioglu, Z., 2021. Benchmarking virus concentration methods for quantification of SARS-CoV-2 in raw wastewater. Sci. Total Environ. 755, 142939.

https://doi.org/10.1016/J.SCITOTENV.2020.142939

Jaroenlak, P., Sanguanrut, P., Williams, B.A.P., Stentiford, G.D., Flegel, T.W., Sritunyalucksana, K., Itsathitphaisarn, O., 2016. A Nested PCR Assay to Avoid False Positive Detection of the Microsporidian Enterocytozoon hepatopenaei (EHP) in Environmental Samples in Shrimp Farms. PLoS One 11, e0166320. https://doi.org/10.1371/JOURNAL.PONE.0166320

Kang, G., 2017. Viral Diarrhea. Int. Encycl. Public Heal. 360. https://doi.org/10.1016/B978-012-803678-5.00486-0

Kapikian, A.Z., 1996. Overview of viral gastroenteritis. Arch. Virol. Suppl. 1996, 7-19. https://doi.org/10.1007/978-3-7091-6553-9_2

Karthikeyan, S., Ronquillo, N., Belda-Ferre, P., Alvarado, D., Javidi, T., Longhurst, C.A., Knight, R., 2021. High-Throughput Wastewater SARS-CoV-2 Detection Enables Forecasting of Community Infection Dynamics in San Diego County. mSystems 6. https://doi.org/10.1128/MSYSTEMS.00045-21/SUPPL_FILE/MSYSTEMS.00045-21ST003.DOCX

Katayama, H., Shimasaki, A., Ohgaki, S., 2002. Development of a Virus Concentration Method and Its Application to Detection of Enterovirus and Norwalk Virus from Coastal Seawater. Appl. Environ. Microbiol. 68, 1033-1039. https://doi.org/10.1128/AEM.68.3.10331039.2002

Kralik, P., Ricchi, M., 2017. A basic guide to real time PCR in microbial diagnostics: Definitions, parameters, and everything. Front. Microbiol. 8, 108. https://doi.org/10.3389/FMICB.2017.00108/BIBTEX

La Rosa, G., Bonadonna, L., Lucentini, L., Kenmoe, S., Suffredini, E., 2020a. Coronavirus in water environments: Occurrence, persistence and concentration methods - A scoping review. Water Res. 179, 115899. https://doi.org/10.1016/J.WATRES.2020.115899

La Rosa, G., Iaconelli, M., Mancini, P., Bonanno Ferraro, G., Veneri, C., Bonadonna, L., Lucentini, L., Suffredini, E., 2020b. First detection of SARS-CoV-2 in untreated wastewaters in Italy. Sci. Total Environ. 736, 139652. https://doi.org/10.1016/J.SCITOTENV.2020.139652 
Larsson, J.M.H., Karlsson, H., Sjövall, H., Hansson, G.C., 2009. A complex, but uniform Oglycosylation of the human MUC2 mucin from colonic biopsies analyzed by nanoLC/MSn. Glycobiology 19, 756-766. https://doi.org/10.1093/GLYCOB/CWP048

LaTurner, Z.W., Zong, D.M., Kalvapalle, P., Gamas, K.R., Terwilliger, A., Crosby, T., Ali, P., Avadhanula, V., Santos, H.H., Weesner, K., Hopkins, L., Piedra, P.A., Maresso, A.W., Stadler, L.B., 2021. Evaluating recovery, cost, and throughput of different concentration methods for SARS-CoV-2 wastewater-based epidemiology. Water Res. 197, 117043. https://doi.org/10.1016/J.WATRES.2021.117043

Lodder, W.J., De Roda Husman, A.M., 2005. Presence of noroviruses and other enteric viruses in sewage and surface waters in The Netherlands. Appl. Environ. Microbiol. 71, 1453-1461. https://doi.org/10.1128/AEM.71.3.1453-1461.2005

Lu, D., Huang, Z., Luo, J., Zhang, X., Sha, S., 2020. Primary concentration - The critical step in implementing the wastewater based epidemiology for the COVID-19 pandemic: A minireview. Sci. Total Environ. 747, 141245. https://doi.org/10.1016/j.scitotenv.2020.141245

Maher, N., Dillon, H.K., Vermund, S.H., Unnasch, T.R., 2001. Magnetic bead capture eliminates PCR inhibitors in samples collected from the airborne environment, permitting detection of Pneumocystis carinii DNA. Appl. Environ. Microbiol. 67, 449-452. https://doi.org/10.1128/AEM.67.1.449-452.2001/ASSET/2BB3A5B0-1602-400E-A0C3C32CFC5AFC72/ASSETS/GRAPHIC/AM0110760003.JPEG

McGuckin, M.A., Lindén, S.K., Sutton, P., Florin, T.H., 2011. Mucin dynamics and enteric pathogens. Nat. Rev. Microbiol. 201194 9, 265-278. https://doi.org/10.1038/nrmicro2538

Nalla, A.K., Casto, A.M., Huang, M.-L.W., Perchetti, G.A., Sampoleo, R., Shrestha, L., Wei, Y., Zhu, H., Jerome, K.R., Greninger, A.L., 2020. Comparative Performance of SARS-CoV-2 Detection Assays Using Seven Different Primer-Probe Sets and One Assay Kit. https://doi.org/10.2807/1560-7917.ES.2020

Nemudryi, A., Nemudraia, A., Wiegand, T., Surya, K., Buyukyoruk, M., Cicha, C., Vanderwood, K.K., Wilkinson, R., Wiedenheft, B., 2020. Temporal Detection and Phylogenetic Assessment of SARS-CoV-2 in Municipal Wastewater. Cell Reports Med. 1, 100098. https://doi.org/10.1016/J.XCRM.2020.100098

Oh, C., Sun, P.P., Araud, E., Nguyen, T.H., 2020. Mechanism and efficacy of virus inactivation by a microplasma UV lamp generating monochromatic UV irradiation at $222 \mathrm{~nm}$. Water Res. 186. https://doi.org/10.1016/j.watres.2020.116386

Panchal, D., Prakash, O., Bobde, P., Pal, S., 2021. SARS-CoV-2: sewage surveillance as an early warning system and challenges in developing countries. Environ. Sci. Pollut. Res. 2021 2818 28, 22221-22240. https://doi.org/10.1007/S11356-021-13170-8

Park, C., Lee, Jina, ul Hassan, Z., Ku, K.B., Kim, S.J., Kim, H.G., Park, E.C., Park, G.S., Park, Daeui, Baek, S.H., Park, Dongju, Lee, Jihye, Jeon, S., Kim, Seungtaek, Lee, C.S., Yoo, H.M., Kim, Seil, 2021. Comparison of Digital PCR and Quantitative PCR with Various SARS-CoV-2 Primer-Probe Sets. J. Microbiol. Biotechnol. 31, 358-367. https://doi.org/10.4014/JMB.2009.09006

Pecson, B.M., Darby, E., Haas, C.N., Amha, Y.M., Bartolo, M., Danielson, R., Dearborn, Y., Di Giovanni, G., Ferguson, C., Fevig, S., Gaddis, E., Gray, D., Lukasik, G., Mull, B., Olivas, L., Olivieri, A., Qu, Y., SARS-CoV-2 Interlaboratory Consortium, 2021. Reproducibility and sensitivity of 36 methods to quantify the SARS-CoV-2 genetic signal in raw wastewater: findings from an interlaboratory methods evaluation in the U.S. Environ. Sci. Water Res. Technol. https://doi.org/10.1039/d0ew00946f 
Philo, S.E., Keim, E.K., Swanstrom, R., Ong, A.Q.W., Burnor, E.A., Kossik, A.L., Harrison, J.C., SARS-CoV-2 wastewater concentration methods for environmental surveillance. Sci. Total Environ. 760, 144215. https://doi.org/10.1016/J.SCITOTENV.2020.144215

Polo, D., Quintela-Baluja, M., Corbishley, A., Jones, D.L., Singer, A.C., Graham, D.W., Romalde, J.L., 2020. Making waves: Wastewater-based epidemiology for COVID-19 approaches and challenges for surveillance and prediction. Water Res. 186, 116404. https://doi.org/10.1016/J.WATRES.2020.116404

Randazzo, W., Truchado, P., Cuevas-Ferrando, E., Simón, P., Allende, A., Sánchez, G., 2020. SARS-CoV-2 RNA in wastewater anticipated COVID-19 occurrence in a low prevalence area. Water Res. 181, 115942. https://doi.org/10.1016/J.WATRES.2020.115942

Rawat, P., Jemimah, S., Ponnuswamy, P.K., Gromiha, M.M., 2021. Why are ACE2 binding coronavirus strains SARS-CoV/SARS-CoV-2 wild and NL63 mild? Proteins Struct. Funct. Bioinforma. 89, 389-398. https://doi.org/10.1002/PROT.26024

Rusiñol, M., Martínez-Puchol, S., Forés, E., Itarte, M., Girones, R., Bofill-Mas, S., 2020. Concentration methods for the quantification of coronavirus and other potentially pandemic enveloped virus from wastewater. Curr. Opin. Environ. Sci. Heal. 17, 21-28. https://doi.org/10.1016/J.COESH.2020.08.002

Satyanarayana, M., 2020. Shortage of RNA extraction kits hampers efforts to ramp up COVID19 coronavirus testing [WWW Document]. URL https://cen.acs.org/analyticalchemistry/diagnostics/Shortage-RNA-extraction-kits-hampers/98/web/2020/03 (accessed 11.23.21).

Schrader, C., Schielke, A., Ellerbroek, L., Johne, R., 2012. PCR inhibitors - occurrence, properties and removal. J. Appl. Microbiol. 113, 1014-1026. https://doi.org/10.1111/j.13652672.2012.05384.x

Sherchan, S.P., Shahin, S., Patel, J., Ward, L.M., Tandukar, S., Uprety, S., Schmitz, B.W., Ahmed, W., Simpson, S., Gyawali, P., 2021. Occurrence of SARS-CoV-2 RNA in Six Municipal Wastewater Treatment Plants at the Early Stage of COVID-19 Pandemic in The United States. Pathog. (Basel, Switzerland) 10. https://doi.org/10.3390/PATHOGENS10070798

Suresh, M., Harlow, J., Nasheri, N., 2019. Evaluation of porcine gastric mucin assay for detection and quantification of human norovirus in fresh herbs and leafy vegetables. Food Microbiol. 84, 103254. https://doi.org/10.1016/J.FM.2019.103254

Tamariz, J., Voynarovska, K., Prinz, M., Caragine, T., 2006. The Application of Ultraviolet Irradiation to Exogenous Sources of DNA in Plasticware and Water for the Amplification of Low Copy Number DNA. J. Forensic Sci. 51, 790-794. https://doi.org/10.1111/J.15564029.2006.00172.X

Uchida, E., Kogi, M., Oshizawa, T., Furuta, B., Satoh, K., Iwata, A., Murata, M., Hikata, M., Yamaguchi, T., 2007. Optimization of the virus concentration method using polyethyleneimine-conjugated magnetic beads and its application to the detection of human hepatitis A, B and C viruses. J. Virol. Methods 143, 95-103. https://doi.org/10.1016/J.JVIROMET.2007.02.014

Walker, D.I., Cross, L.J., Stapleton, T.A., Jenkins, C.L., Lees, D.N., Lowther, J.A., 2019. Assessment of the Applicability of Capsid-Integrity Assays for Detecting Infectious Norovirus Inactivated by Heat or UV Irradiation. Food Environ. Virol. 11, 229-237. https://doi.org/10.1007/s12560-019-09390-4 
Waruhiu, C., Ommeh, S., Obanda, V., Agwanda, B., Gakuya, F., Ge, X.Y., Yang, X. Lou, Wu, L.J., Zohaib, A., Hu, B., Shi, Z.L., 2017. Molecular detection of viruses in Kenyan bats and discovery of novel astroviruses, caliciviruses and rotaviruses. Virol. Sin. 2017322 32, 101114. https://doi.org/10.1007/S12250-016-3930-2

Wolfe, M.K., Archana, A., Catoe, D., Coffman, M.M., Dorevich, S., Graham, K.E., Kim, S., Grijalva, L.M., Roldan-Hernandez, L., Silverman, A.I., Sinnott-Armstrong, N., Vugia, D.J., Yu, A.T., Zambrana, W., Wigginton, K.R., Boehm, A.B., 2021. Scaling of SARS-CoV-2 RNA in Settled Solids from Multiple Wastewater Treatment Plants to Compare Incidence Rates of Laboratory-Confirmed COVID-19 in Their Sewersheds. Environ. Sci. Technol. Lett. 8, 398-404. https://doi.org/10.1021/ACS.ESTLETT.1C00184

Wu, Q., Kawano, K., Uehara, Y., Okuda, N., Hongo, M., Tsuji, S., Yamanaka, H., Minamoto, T., 2018. Environmental DNA reveals nonmigratory individuals of Palaemon paucidens overwintering in Lake Biwa shallow waters. Freshw. Sci. 37, 307-314. https://doi.org/10.1086/697542/ASSET/IMAGES/LARGE/FG3.JPEG

Ye, Y., Ellenberg, R.M., Graham, K.E., Wigginton, K.R., 2016. Survivability, Partitioning, and Recovery of Enveloped Viruses in Untreated Municipal Wastewater. Environ. Sci. Technol. 50, 5077-5085. https://doi.org/10.1021/ACS.EST.6B00876/SUPPL_FILE/ES6B00876_SI_001.PDF

Yu, G., Zhang, D., Guo, F., Tan, M., Jiang, X., Jiang, W., 2013. Cryo-EM Structure of a Novel Calicivirus, Tulane Virus. PLoS One 8, 59817. https://doi.org/10.1371/journal.pone.0059817

Zhu, Y., Oishi, W., Maruo, C., Saito, M., Chen, R., Kitajima, M., Sano, D., 2021. Early warning of COVID-19 via wastewater-based epidemiology: potential and bottlenecks. Sci. Total Environ. 767, 145124. https://doi.org/10.1016/J.SCITOTENV.2021.145124

890 